\title{
FINANCIAL DEVELOPMENT AND ECONOMIC GROWTH IN POLAND 1990-2018
}

\author{
Marinko ŠKARE ${ }^{*}$ (D), Dean SINKOVIĆ ${ }^{2}$ (D), \\ Małgorzata PORADA-ROCHON ${ }^{3}$ \\ 1,2Faculty of Economics and Tourism "Dr. Mijo Mirković", \\ Juraj Dobrila University of Pula, Pula, Croatia \\ ${ }^{3}$ Faculty of Management and Economics of Services, \\ University of Szczecin, Szczecin, Poland
}

Received 25 August 2018; accepted 22 November 2018

\begin{abstract}
The aim of the paper is to study finance-economic growth nexus in Poland using a time series approach. We find evidence of the existence of the finance-economic growth link in Poland. Most empirical studies do not consider the lending structure of the financial sector (share of households' vs firms in total credits). The obtained results show that when using the share of households and companies in total credits, the long run empirical relationship in VECM is statistically significant and larger. Empirical studies using total private credit share in the GDP or the value/ volume of total credits tend to undervalue the impact of financial development on economic growth. In the case of Poland, empirical evidence that supports this hypothesis was found, and therefore policymakers and researchers should take bank lending structure into account. Furthermore, the study shows that financial series may possibly have long memory properties and that researching the financial development-growth nexus could require using fractional integration methods. The reported evidence suggests financial development plays a significant role in both economic growth and credit growth. Due to data limitation, this study focuses on a single country case - Poland with the need for further research (larger sample).
\end{abstract}

Keywords: financial development, economic growth, transition, Poland.

JEL Classification: G2, O11, O23, O47.

\section{Introduction}

Parallel with the construction of endogenous growth theories, the economic literature linking financial development to growth has become one of the major research areas in the last 20 years. Although the first evidence of a positive correlation between economic growth and the level of financial development was found in the works of Goldsmith (1969) and McKinnon

\footnotetext{
*Corresponding author. E-mail: mskare@unipu.hr
} 
(1973), it was the paper by King and Levine (1993) that catalyzed this research at both the macro and micro level. Similar findings were reported in the later empirical studies using a more sophisticated econometric methodology ${ }^{1}$.

To study the finance-growth link we use the Poland case. Main reason for selecting Poland for the study is that Poland was among the countries not greatly affected by the financial crisis of 2008. Asteriou and Spanos (2018) investigated the relationship between financial development and economic growth in the face of the recent financial crisis, using a panel dataset of 26 European Union countries over the period 1990-2016. The results show that before the crisis, financial development promoted economic growth, while after the crisis it hindered economic activity. The degree of international trade openness in the economy of a country was the primary factor that led growth during both crisis periods. The importance and novelty of our study is in using modern econometric techniques to explore the long memory properties of the finance-growth relationship. Our study contributes to the existent body of literature on the finance-growth link by studying long memory properties of the series. We find that fractional integration techniques studying this issue provide more robust scientific results in relation to previous studies not addressing the persistence issue.

Although there is a degree of consensus that financial development stimulates economic growth, there are still some ambiguities in the empirical research. The key problems are associated with the issue of causality, the nonlinearity component, the long-term versus short term impact and the financial variables (indicators) used in the research. In regard to the causality issue, the key question tends to remain the same - is financial development a precondition for economic growth, or do financial intermediaries and their products develop in parallel with economic development? The empirical outcomes could be classified within three groups; the first implies that financial development follows economic development (demand-driven finance) ${ }^{2}$, the second emphasizes that financial development crucially affects the speed of economic development (supply driven finance) ${ }^{3}$, and the third stresses that the causality runs both ways ${ }^{4}$. The overall consensus has been reached around the third group of results, implying that causality between finance and growth runs both ways, therefore accepting the assumptions concerning both demand-driven and supply-driven finance. This conclusion seems entirely logical when observed from a theoretical standpoint. On the one hand, it is obvious that the main engines of growth, such as physical and human capital accumulation, technology advancement and innovative projects need efficient and well-developed financial intermediation. On the other, technological advancement and the creation of more sophisticated equipment affect the development of more efficient financial products and services. Yet the second and third problems, concerning nonlinearity and long term versus short term impact issues, are not completely tackled by empirical researchers. Deidda and Fattouh

\footnotetext{
1 See Rousseau and Wachtel (2000), Benhabib and Spiegel (2000), Beck, Levine and Loayza (2000), Beck and Levine (2002), Favara (2003), Calderón and Liu (2003), Christopoulos and Tsionas (2004), Loayza and Ranciere (2005), Demetriades and Law (2006), Bordo and Rousseau (2006), Ahlin and Pang (2008), etc.

2 See Demetriades and Hussein (1996), Koivu (2002), Zang and Kim (2007).

${ }^{3}$ See King and Levine (1993), Odedokun (1996), Christopoulos and Tsionas (2004).

${ }^{4}$ See Berthelemy and Varoudakis (1996), Levine (1997) Neusser and Kugler (1998), Demetriadesa and Hussein (1996), Rousseau and Wachtel (2002), Luintel and Khan (1999), Calderon and Liu (2003).
} 
(2002) found a non-linear relationship between financial development and growth across a large set of countries. They concluded that the correlation depends on the level of a country's economic development ${ }^{5}$. Quite contrary to this, Favara (2003) pointed out that nonlinearity exists regardless of a country's economic status or regional traits. Rams (1999) results stressed that the problems of nonlinearity might be related to the econometric methods used in the majority of research on this subject. He found that individual-country correlation results are in sharp contrast to the correlations based on the cross-country data mostly used by researchers. This implies that using cross country or panel data in research might result in ambiguous outcomes and false conclusions concerning the finance and growth nexus for an individual country. Another way to tackle the problem of nonlinearity is highlighted by Demetriades and Hussein (1996), whose research pointed to the fact that this issue might be caused by other factors, such as the institutional, legal and political framework pertaining in a certain economy. The third way to explain the problem of nonlinearity is related to the financial indicators used by researchers. Beck, Buyukkarabacak, Rioja, and Valev (2008) tackled this problem by decomposing private sector credit into household and firm credit and found that it is lending to enterprises, not to households, that drives the positive impact of financial development on economic growth ${ }^{6}$. The last findings may actually shed some light on the solution to several aforementioned problems associated with the finance-growth nexus research. Supply-leading hypothesis seems to hold for the large part of the manufacturing sector Topcu and Çoban (2017).

From a theoretical perspective, household and enterprise credits have a different impact on economic growth. The crucial focus of theoretical models that include variables of financial intermediation is mostly put on the enterprise's need for external financing, in order to underpin its productive investment plans ${ }^{7}$. The key theoretical assumption is that financial intermediaries emerge due to market frictions (information and transaction costs) and encourage the mobilization of savings, better risk management, corporate control and allocation of resources, through which development of the financial institutions stipulate accumulation of capital and productivity growth (Levine, 1997). While these theoretical assumptions are mostly supported by empirical work, both theory and empirical work linking household credit to economic growth provide some ambiguous conclusions ${ }^{8}$. Galor and Zeira (1993) and De Gregorio (1996) claim that household credit can stimulate economic growth if funds are channelled toward human capital accumulation. On the other hand, Jappelli and Pagano (1994) pointed out that loosened credit constraints on households result in lower saving rates and lower economic growth.

\footnotetext{
5 The strongest link between finance and growth was found in middle income countries. Similar results are found in the research of Rioja and Valev (2004a, 2004b), Demetriades and Law (2006) and Fink, Haiss and Mantler (2005).

${ }^{6}$ Authors constructed disaggregated dataset of bank credit for 45 developed and developing countries. To assess the impact of different credit structures on GDP per capita they used cross country regression controlling for other factors of economic growth; the long of initial GDP per capita to control for convergence, secondary school enrolment to contol for human capital accumulation, the share of exports and imports on GDP, the inflation rate and the ratio of government expenditures to GDP.

7 See Levine (2005) for extensive overview.

${ }^{8}$ Furthermore, the research was conducted only for OECD countries.
} 
The empirical literature is almost exclusively focused on aggregate credit measures, known as private credit, which include both household and enterprise credits ${ }^{9}$. Bearing in mind the huge spike of household lending in most of developed and developing countries, understanding the effect of credit composition on economic performance could lead to some important repercussions for the theory. If household and enterprise lending have an independent impact on growth, it might shape our understanding of why the effect of financial development on economic growth varies across countries, as well as provide some important insights regarding the channels through which financial intermediaries stimulate GDP growth (see Beck et al., 2008). Financial repression policies have strong impact on the finance-growth link (Yülek, 2017) as well as monetary freedom (Ivanović \& Stanišić, 2017).

This paper assesses whether household and enterprise lending have different impact on real GDP growth in Poland. The paper is organized as follows. Section II provides and overview on studies examining financial development, lending and economic growth nexus. Section III discusses the methodology and main variables used in the model. Section IV presents the results and Section V provides some concluding remarks.

\section{Literature review}

Although a large body of literature on the relationship between finance and economic growth exists, the channel of transmission between two phenomena remains unexplained. Empirical evidence of previous studies supporting conclusion in favor of supply-leading or demandfollowing hypothesis remains open for debate.

Table 1 lists contemporary empirical studies on the finance and economic growth nexus from the last few years. Most of the patented research on the relationship between financial development and economic growth relates to multinational research, much less to individual economies. We summarize these studies below from the oldest to the newest ones, thus showing a rise in interest.

Gómez-Puig and Sosvilla-Rivero (2018) analysed the effects of all sources of nonfinancial debt (household, corporate as well as government) accumulation on economic growth in ten euro-zone countries during the period 1980-2015. By using three models (a baseline, an asymmetric and a threshold model), the scientists found that while public debt thresholds are higher in peripheral than in central countries, private debt thresholds are higher in core euro-area countries. Thus, in particular with regard to peripheral countries, the reduction of private debt and household debt should be the key to stimulating economic growth.

Ruiz (2018) analyses the nonlinear relationship between financial development and economic growth over the period 1991-2014 by examining 116 economies (industrialized and developing economies). Using the dynamic panel threshold model, they found two regimeindependent effects for the finance variables (bank credit to the private sector or domestic credit to the private sector). They report a positive and statistically significant effect of private sector credit on economic growth in both developing (pension funds as the institutional investor) and industrialized (all three types of institutional investors) economies.

\footnotetext{
${ }^{9}$ Private credit or value of credit to the private sector by deposit money banks represents standard indicator of financial development and is in most of empirical research linking finance and economic growth.
} 
Table 1. Review of empirical studies on finance and economic growth relationship (source: authors' review)

\begin{tabular}{|c|c|c|c|}
\hline Study & Study purpose & $\begin{array}{l}\text { Time frame / } \\
\text { Sample }\end{array}$ & Relevant findings \\
\hline $\begin{array}{l}\text { Gómez-Puig } \\
\text { and } \\
\text { Sosvilla-Rivero } \\
(2018)\end{array}$ & $\begin{array}{l}\text { The effects of nonfinancial debt } \\
\text { on economic growth in EMU } \\
\text { countries }\end{array}$ & $\begin{array}{l}1980-2015 \\
10 \\
\text { euro-zone } \\
\text { countries }\end{array}$ & $\begin{array}{l}\text { There exists a relationship } \\
\text { between the impact of } \\
\text { nonfinancial debt on } \\
\text { economic growth, however } \\
\text { it clearly differs between } \\
\text { countries. }\end{array}$ \\
\hline Ruiz (2018) & $\begin{array}{l}\text { The nonlinear relationship } \\
\text { between financial development } \\
\text { under the presence of } \\
\text { institutional investors (assets in } \\
\text { insurance companies, mutual } \\
\text { funds, and pension funds, as } \\
\text { a percentage of GDP) and } \\
\text { economic growth }\end{array}$ & \begin{tabular}{|l|}
$1991-2014$ \\
116 countries
\end{tabular} & $\begin{array}{l}\text { Two regime-independent } \\
\text { effects for the finance } \\
\text { variables were found (bank } \\
\text { credit to the private sector or } \\
\text { domestic credit to the private } \\
\text { sector). }\end{array}$ \\
\hline $\begin{array}{l}\text { Asteriou and } \\
\text { Spanos (2018) }\end{array}$ & $\begin{array}{l}\text { The relationship between } \\
\text { financial development and } \\
\text { economic growth in the face of } \\
\text { the recent financial crisis }\end{array}$ & $\begin{array}{l}1990-2016 \\
26 \text { European } \\
\text { Union countries }\end{array}$ & $\begin{array}{l}\text { Before the crisis, financial } \\
\text { development promoted } \\
\text { economic growth, while } \\
\text { after the crisis it hindered } \\
\text { economic activity. }\end{array}$ \\
\hline $\begin{array}{l}\text { Ibrahim and } \\
\text { Alagidede } \\
\text { (2018) }\end{array}$ & $\begin{array}{l}\text { The economic growth affects } \\
\text { when the financial development } \\
\text { and the real sector growth are } \\
\text { unbalanced }\end{array}$ & $\begin{array}{l}1980-2014 \\
29 \text { sub-Saharan } \\
\text { African }\end{array}$ & $\begin{array}{l}\text { Financial development } \\
\text { supports economic growth, } \\
\text { the extent, to which finance } \\
\text { helps growth, depends } \\
\text { crucially on the simultaneous } \\
\text { growth of real and financial } \\
\text { sectors. }\end{array}$ \\
\hline $\begin{array}{l}\text { Afonso and } \\
\text { Blanco-Arana } \\
(2018)\end{array}$ & $\begin{array}{l}\text { The relationship between } \\
\text { economic growth and financial } \\
\text { development }\end{array}$ & $\begin{array}{l}\text { 1990-2016 } \\
\text { OECD countries }\end{array}$ & $\begin{array}{l}\text { There is a positive and } \\
\text { statistically significant } \\
\text { relationship between the } \\
\text { three indicators of financial } \\
\text { development and GDP per } \\
\text { capita. }\end{array}$ \\
\hline Léon (2018b) & Convergence of credit structure & \begin{tabular}{|l|}
$1995-2014$ \\
143 countries
\end{tabular} & $\begin{array}{l}\text { The convergence of } \\
\text { household credit occurs } \\
\text { faster than in the case of firm } \\
\text { credit, inducing a process } \\
\text { of convergence of the share } \\
\text { of household credit in total } \\
\text { credit. }\end{array}$ \\
\hline $\begin{array}{l}\text { Bahadir and } \\
\text { Valev (2017) }\end{array}$ & Convergence of credit structure & $\begin{array}{l}1995-2013 \\
\text { 30 European } \\
\text { countries }\end{array}$ & $\begin{array}{l}\text { The convergence of credit } \\
\text { levels is stronger for } \\
\text { household credit, including } \\
\text { housing loans and consumer } \\
\text { credit, when compared to } \\
\text { business credit. }\end{array}$ \\
\hline
\end{tabular}


Continue of Table 1

\begin{tabular}{|c|c|c|c|}
\hline Study & Study purpose & $\begin{array}{l}\text { Time frame / } \\
\text { Sample }\end{array}$ & Relevant findings \\
\hline $\begin{array}{l}\text { Ganiyu, } \\
\text { Amoo, } \\
\text { Eboreime, and } \\
\text { Maximillian } \\
(2017)\end{array}$ & $\begin{array}{l}\text { The effect of private sector } \\
\text { credit on economic growth }\end{array}$ & $\begin{array}{l}\text { 1993-2013 } \\
\text { Nigeria }\end{array}$ & $\begin{array}{l}\text { Private sector credit } \\
\text { positively and significantly } \\
\text { affected economic growth } \\
\text { after controlling for local } \\
\text { conditions and the policy } \\
\text { environment. }\end{array}$ \\
\hline $\begin{array}{l}\text { Durusu-Ciftci, } \\
\text { SerdarIspir, } \\
\text { and Yetkiner } \\
(2017)\end{array}$ & $\begin{array}{l}\text { The theoretical and empirical } \\
\text { role of financial development on } \\
\text { economic growth }\end{array}$ & $\begin{array}{l}1989-2011 \\
40 \text { countries }\end{array}$ & $\begin{array}{l}\text { Both credit market } \\
\text { development and stock } \\
\text { market development have } \\
\text { positive long-run effects on } \\
\text { steady-state level of GDP per } \\
\text { capita. Financial development } \\
\text { plays a role in economic } \\
\text { growth for the majority } \\
\text { of sample countries studied. }\end{array}$ \\
\hline Ono (2017) & $\begin{array}{l}\text { The finance-growth nexus in } \\
\text { Russia }\end{array}$ & $\begin{array}{l}1999 \text { to } 2008 \\
\text { (Subperiod } 1 \text { ) } \\
2009 \text { to } 2014 \\
\text { (Subperiod 2) } \\
\text { Russia }\end{array}$ & $\begin{array}{l}\text { Russian banks do not play } \\
\text { the role of leading economic } \\
\text { growth. }\end{array}$ \\
\hline $\begin{array}{l}\text { Chudik, } \\
\text { Mohaddes, } \\
\text { Pesaran, and } \\
\text { Raissi (2017) }\end{array}$ & $\begin{array}{l}\text { The long-run impact of public } \\
\text { debt expansion on economic } \\
\text { growth }\end{array}$ & $\begin{array}{l}1965-2010 \\
40 \text { countries }\end{array}$ & $\begin{array}{l}\text { There is no evidence for } \\
\text { a universally applicable } \\
\text { threshold effect in the } \\
\text { relationship between public } \\
\text { debt and economic growth. }\end{array}$ \\
\hline $\begin{array}{l}\text { Belinga, Zhou, } \\
\text { Doumbe- } \\
\text { Doumbe, } \\
\text { Gahe, \& Koffi } \\
(2016)\end{array}$ & $\begin{array}{l}\text { The causal relationship between } \\
\text { bank credit and economic } \\
\text { growth in Cameroon }\end{array}$ & $\begin{array}{l}\text { 1969-2013 } \\
\text { Cameroon }\end{array}$ & $\begin{array}{l}\text { Causality running from bank } \\
\text { credit to gross domestic } \\
\text { product, implying that } \\
\text { monetary policies in favour } \\
\text { of banking credit will } \\
\text { definitely boost the economic } \\
\text { development of Cameroon. }\end{array}$ \\
\hline Léon (2016) & $\begin{array}{l}\text { The effects of household and } \\
\text { enterprise credit on economic } \\
\text { growth }\end{array}$ & $\begin{array}{l}1995-2014 \\
143 \text { countries } \\
(126 \text { countries } \\
\text { were included } \\
\text { in econometric } \\
\text { analysis) }\end{array}$ & $\begin{array}{l}\text { Recent evidence documenting } \\
\text { the absence of the effect } \\
\text { of total credit on growth. } \\
\text { Moreover, findings show } \\
\text { that household credit has a } \\
\text { negative effect on growth, } \\
\text { but it fails to provide robust } \\
\text { support for a positive effect } \\
\text { of business credit. }\end{array}$ \\
\hline $\begin{array}{l}\text { Angjelkovska, } \\
\text { Hani, and } \\
\text { Eliskovski } \\
(2016)\end{array}$ & $\begin{array}{l}\text { The effects of the decomposed } \\
\text { private sector credit on } \\
\text { economic growth }\end{array}$ & $\begin{array}{l}\text { 1995-2014 } \\
\text { Albania, Bosnia } \\
\text { and Herzegovina, } \\
\text { Bulgaria, Croatia, } \\
\text { Macedonia, } \\
\text { Romania, Serbia } \\
\text { and Turkey }\end{array}$ & $\begin{array}{l}\text { Enterprise credits are } \\
\text { positively related with } \\
\text { economic growth, whereas } \\
\text { for the household credits the } \\
\text { result is ambiguous. }\end{array}$ \\
\hline
\end{tabular}


End of Table 1

\begin{tabular}{|l|l|l|l|}
\hline \multicolumn{1}{|c|}{ Study } & \multicolumn{1}{|c|}{ Study purpose } & \multicolumn{1}{c|}{$\begin{array}{c}\text { Time frame/ } \\
\text { Sample }\end{array}$} & \multicolumn{1}{c|}{ Relevant findings } \\
\hline $\begin{array}{l}\text { Folwarski } \\
(2016)\end{array}$ & $\begin{array}{l}\text { The relationship between credits } \\
\text { and economics growth }\end{array}$ & $\begin{array}{l}2005-2015 \\
\text { Poland }\end{array}$ & $\begin{array}{l}\text { Credits for households and } \\
\text { enterprises significantly affect } \\
\text { economic growth. }\end{array}$ \\
\hline $\begin{array}{l}\text { Hasan, } \\
\text { Horvath, and } \\
\text { Mares (2016) }\end{array}$ & $\begin{array}{l}\text { The effect of finance on long- } \\
\text { term economic growth }\end{array}$ & $\begin{array}{l}1960-2011 \\
72 \text { countries }\end{array}$ & $\begin{array}{l}\text { Commonly used indicators } \\
\text { of financial development are } \\
\text { not robustly related to long- } \\
\text { term growth. }\end{array}$ \\
\hline $\begin{array}{l}\text { Ductor and } \\
\text { Grechyna } \\
\text { (2015) }\end{array}$ & $\begin{array}{l}\text { The interdependence between } \\
\text { financial development and real } \\
\text { sector output and the effect on } \\
\text { economic growth }\end{array}$ & $\begin{array}{l}1970-2010 \\
101 \text { countries }\end{array}$ & $\begin{array}{l}\text { Non-linear relationship } \\
\text { between financial } \\
\text { development and growth. }\end{array}$ \\
\hline $\begin{array}{l}\text { Samargandia, } \\
\text { Fidrmuc, and } \\
\text { Ghosh (2015) }\end{array}$ & $\begin{array}{l}\text { The relationship between } \\
\text { financial development and } \\
\text { economic growth }\end{array}$ & $\begin{array}{l}1980-2008 \\
52 \text { countries }\end{array}$ & $\begin{array}{l}\text { An inverted U-shaped } \\
\text { relationship between finance } \\
\text { and growth in the long run. }\end{array}$ \\
\hline $\begin{array}{l}\text { Sassi and } \\
\text { Gasmi (2014) }\end{array}$ & $\begin{array}{l}\text { The effects of enterprise credit } \\
\text { market and household credit } \\
\text { market on economic growth }\end{array}$ & $\begin{array}{l}1995-2012 \\
27 \text { European } \\
\text { countries }\end{array}$ & $\begin{array}{l}\text { Household credit has a } \\
\text { negative effect on economic } \\
\text { growth in European } \\
\text { countries. } \\
\text { Enterprise credit boosts } \\
\text { economic growth. }\end{array}$ \\
\hline $\begin{array}{l}\text { Jedidia, } \\
\text { Boujelbènec, } \\
\text { and Helali } \\
\text { (2014) }\end{array}$ & $\begin{array}{l}\text { The effects of financial } \\
\text { development on economic } \\
\text { growth }\end{array}$ & $\begin{array}{l}\text { The domestic credit to } \\
\text { Tunisia } \\
\text { private sector has a positive } \\
\text { effect on economic growth } \\
\text { suggesting that the financial } \\
\text { development is a driver of a } \\
\text { long term economic growth. }\end{array}$ \\
\hline
\end{tabular}

Ibrahim and Alagidede (2018) evaluated economic growth effects when the growth in financial development and that of the real sector is unbalanced, relying on data for 29 subSaharan African countries investigated over the period 1980-2014. They have found that financial development positively affects growth, albeit non-monotonically with inflection points ranging between 27 to $29 \%$. Overall economic growth effect is contingent on the relative speed of growth in finance and that of real sector output.

Afonso and Blanco-Arana (2018) re-examine the relationship between economic growth and the main determinants of financial development in OECD countries during the period 1990-2016. They found at least two different results. An increase in domestic credit provided by financial-sector, in market capitalization and in the turnover ratio of domestic shares entails a significant positive effect on the GDP per capita but different effects during crisis period.

Léon (2018b) analyses convergence of credit structure using an original database and focusing on the breakdown between household credit and firm credit. The scientists applied data collected from diverse sources regarding 143 countries examined over the period 1995-2014. The obtained data show that countries whose financial development was limited, 
experienced a more rapid growth of total, household and firm credits, thus confirming the phenomenon of convergence. The results show that the low-income countries that experienced an initial low level of financial depth prior to 2008 experienced a generally faster convergence process.

Bahadir and Valev (2017) studied household and business credit convergence in Europe over the period 1995-2013 in 30 European countries. Their results led to a conclusion that the process of financial convergence may slow down over time, and that it is stronger in the case of transition economies. Moreover, it was found out that convergence is mostly related to household credit, in the case of which it may offset the benefits of financial convergence.

Ganiyu et al. (2017) investigated the role of private sector credit on economic growth in the Nigerian economy for the period 1993:Q1 to 2013:Q4 using fully modified least squares. They found that credit plays a role of growth enhancer, even in a situation when trade openness, monetary policy, investment climate and infrastructure are low. Furthermore, when domestic or local conditions were favourable, economic growth was increased thanks to private sector credit, whereas the absorptive capacity of the domestic economy for credit was estimated at 29\% of the GDP in 2013.

Durusu-Ciftci et al. (2017) investigated the role of financial development on economic growth for a panel of 40 countries over the period 1989-2011. Although the cross-sectional findings differ among various countries, the panel data analyses indicated that both channels positively affected steady-state level of GDP per capita in the long run, and that contribution of the credit markets is significantly greater.

The finance-growth nexus in Russia with the vector autoregression model was investigated by Ono (2017). The analysis covered the period 1999-2008 (Subperiod 1) and 20092014 (Subperiod 2). The results regarding Subperiod 1 confirm the causality from economic growth to money supply and bank lending, which, in turn, implies demand-following responses. On the other hand, Subperiod 2 indicates that economic growth. Granger results in bank lending with no causality from money supply to economic growth. This can be a result of the dramatic decrease in the amount of intervention in foreign exchange markets.

Chudick et al. (2017) analysed the long-run impact of public debt expansion on economic growth. They used data obtained from examining a sample of 40 countries (grouped into advanced and developing) over the period 1965-2010. They found significant negative, long-run effects of public debt build-up on output growth. Provided that public debt is on a downward trajectory, it was shown that a country with a high level of debt can grow just as fast as its peers in the long run.

Belinga et al. (2016) examined the causal relationship between bank credit and economic growth in Cameroon over the period 1969-2013. Their findings confirm that financial development, including banking credit, does cause economic growth.

Léon (2016) investigated the effects of household and enterprise credit on economic growth using data regarding 143 countries (126 countries are employed for econometric analysis) over the period 1995-2014. The evidence shows that household credit has a negative effect on economic growth in European countries, whereas enterprise credit boosts economic growth. The credit-growth nexus is determined by credit composition. 
Angjelkovska et al. (2016) analysed the effects of the decomposed private sector credit on economic growth and real effective exchange rate (REER) dynamics. They used data obtained from 8 countries (SSE) examined over the period 1995-2014. Based on their findings, it can be concluded that credit allocated to enterprises speeds up the economic growth, while the results regarding the household credits are ambiguous.

Folwarski (2016) examined a link between credits and economics growth in Poland during the period 2005-2015. The findings confirm that both kinds of credits significantly affect economic growth.

Hasan et al. (2016) examined the finance-growth nexus using data of 60 countries for the period 1960-2011. The main finding of the study is that the measurement of financial development is crucial in determining the estimated effect of finance on growth. The efficiency of financial intermediaries, used as newly developed indicator, is robustly related to long-term growth. Furthermore, a greater importance of the banking sector in improving the economic growth was emphasized.

Ductor and Grechyna (2015) evaluated the interdependence between financial development and real sector output as well as the effect on economic growth, using panel data for 101 countries over the period 1970-2010. The findings show that the positive effect of finance on growth is maximum under balanced growth of financial and real sectors. A fast financial development that does not take place simultaneously with growth in the real sector minimizes the positive influence financial development has on growth. In fact, this impact may be negative in the case of financial development that is faster than real output.

Samargandia et al. (2015) analysed relationship between financial development and economic growth using data regarding 52 middle income countries from 1980 to 2008. They found evidence of an inverted U-shaped relationship in the long run, that was, however insignificant in short run. It has been suggested that too strong financing may negatively affect growth in middle-income countries.

Using a sample of 27 European countries over the period 1995-2012, Sassi and Gasmi (2014) examined the effects of private credit and firm credit on economic growth. The results proved that enterprise credit accelerates economic growth, whereas household credit has an opposite effect. This may explain the issue of finance-growth, thanks to the fact that the total credits allocated to private sectors constitute mainly of household credits. Lending in use for productive investments and innovations drive the positive effect of credit market development on economic growth.

Jedidia et al. (2014) re-examines the link between financial development and economic growth in Tunisia during the period 1973-2008. The results produce evidence to support that the domestic credit to private to private sector has positive effect on the economic growth which means that the financial development is a motor of the long term economic growth but at the same time leads to financial fragility at the short run.

This article adopts time series cointegration techniques to study finance and economic growth nexus in Poland using disaggregated variable of total private credits. 


\section{Bank lending and composition of credit in CEE countries}

The latest EBRD report (2017-18) (European Bank of Reconstruction and Development, 2017) grants financial stability of Poland's financial system above the reaching transition score of 7.64, that is close to Slovakia, Slovenia and Latvia. These countries achieved top transition scores on financial stability among all other transitional economies. The only exception is Estonia with a financial stability transition score of 8.19.

Total financial lending in Croatia and Poland share a similar trend during 1994-2015 (see Figure 1).

Figure 1 shows an upward trend in the financial lending in Poland with few exogenous shocks in the series. Lending in Poland was more stable during 1990-2007, in relation to other CEE countries. As it can be seen, the financial crisis of 2008 had an immediate effect on Poland, resulting in an abrupt decline of credit lending. The average size of financial lending in Poland during the observed period amounted to $33 \%$ of GDP. There can be observed a strong correlation between financial lending and economic growth in Poland. This points to a possible causality between the level of finance lending and economic growth in Poland.

During the financial crisis of 2008, Poland did not experience an output cycle. Quite the opposite - during 2008-2015, cumulative gross domestic product growth rate in Poland was $21.5 \%$. Output and credit cycles in Poland appeared to be less volatile and more synchronized in relation to other CEE countries. Figure 2 presents a possible positive two-dimensional causality between output and credit cycles in Poland, which were tested in the next section. The main difference between Poland and other banking sectors of transitional countries arise from the monetary policy adopted by respective central banks in these countries. In CEE countries, these demand/supply of foreign denominated loans (mainly mortgage loans) played a significant role up to a point, which was determined by the role of the National central bank in monetary policy. Consequently, in all CEE countries, the level of foreign denominated loans rose rapidly, see Table 2 .

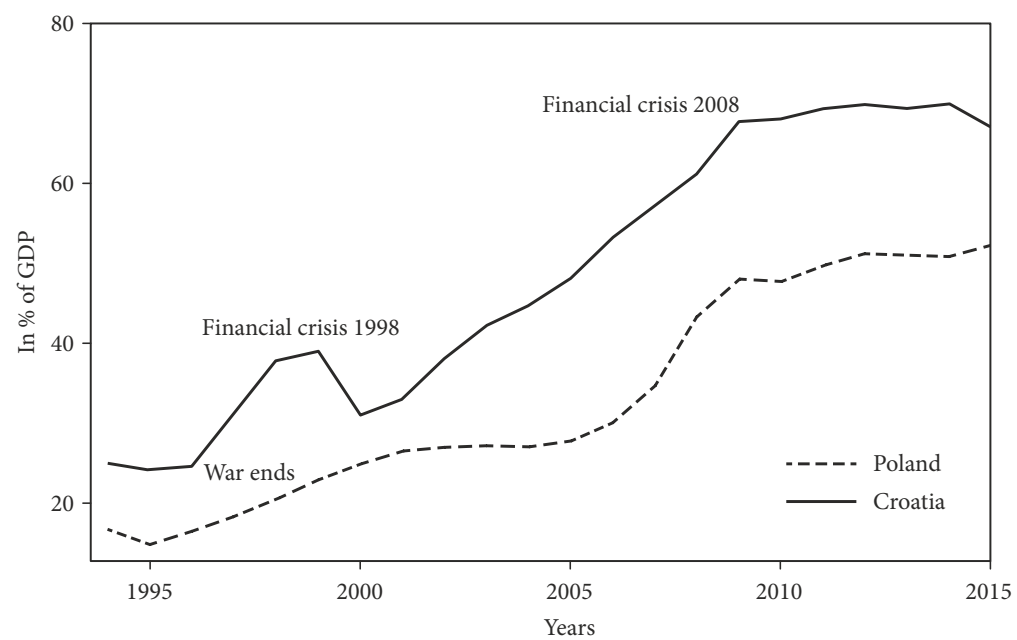

Figure 1. Financial lending in Croatia and Poland 1994-2015

(source: The World Bank, 2018a; Komisja Nadzoru Finansowego [KNF], June 2018) 


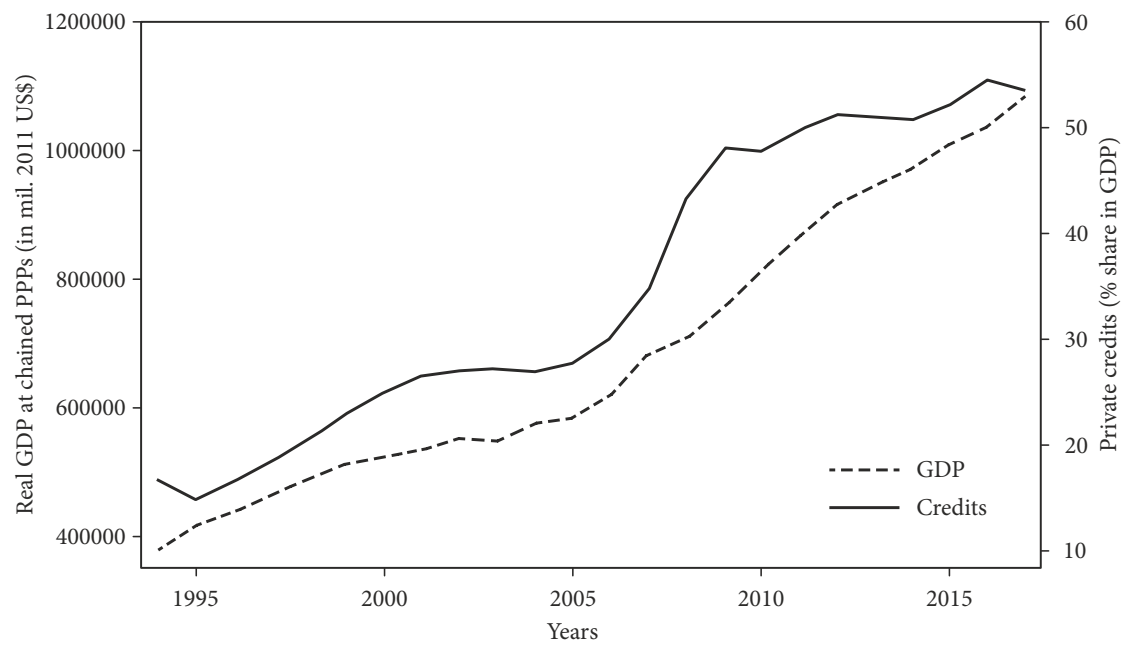

Figure 2. Real GDP and lending dynamics in Croatia and Poland 1994-2017 (source: The World Bank, 2018a; Penn World Table 9.0, 2018; KNF, June 2018)

Table 2. Loans in foreign currency (\% of total credits) 2012-2016 in selected CEE countries (source: Deuber, 2017)

\begin{tabular}{|l|c|c|c|c|c|}
\hline \multicolumn{1}{|c|}{ Country } & 2012 & 2013 & 2014 & 2015 & 2016 \\
\hline Albania & 65 & 63 & 62 & 61 & 59 \\
\hline Bosnia and Hercegovina & 1.6 & 1.6 & 1.4 & 1.3 & 1.2 \\
\hline Belarus & 45 & 50 & 51 & 57 & 56 \\
\hline Bulgaria & 64 & 61 & 57 & 51 & 45 \\
\hline Croatia & 75 & 74 & 74 & 71 & 66 \\
\hline Czech Republic & 15 & 18 & 19 & 19 & 20 \\
\hline Hungary & 55 & 51 & 51 & 23 & 22 \\
\hline Poland & $\mathbf{3 2}$ & $\mathbf{3 0}$ & $\mathbf{2 9}$ & $\mathbf{2 9}$ & $\mathbf{2 7}$ \\
\hline Romania & 63 & 61 & 57 & 50 & 43 \\
\hline Russia & 17 & 18 & 25 & 32 & 27 \\
\hline Serbia & 72 & 72 & 66 & 71 & 67 \\
\hline Slovakia & 1.4 & 1.0 & 1.5 & 0.6 & 0.6 \\
\hline Ukraine & 37 & 34 & 47 & 56 & 50 \\
\hline
\end{tabular}

When compared to all other selected CEE countries listed in Table 2, it can be observed that share of foreign currency denominated loans in total loans is the highest in Croatia. The real extent of foreign currency lending is visible when compared with Poland's, ranging from $27-32 \%$ of total credits, and Croatia's $-66-75 \%$. Countries following Croatia with similar share of foreign currency denominated loans are Serbia, Bulgaria, Romania and Albania. It is noticeable that central banks in CEE countries pursued an active and tight monetary policy, however, not as tight as in the case of Croatia. Crucial point was made by central banks in 
declaring the current and future status of their national currencies. In Croatia, Kuna served as national currency from the very beginning, however, it was predetermined to be a "weak" currency in relation to DEM (Deutch Mark) and later EUR. General argument is that people do not have faith in Kuna, but experience shows that in other CEE countries the general distrust was at the same level. The difference lies in the role central banks attributed to the national currency from the start of the transition process. Monetary tightening in Croatia led to import driven growth, deindustrialization, risk aversion, volatility and systemic banking risks, slow growth and 230 thousand people unable to service their personal debt. Consequently, the financial system was developed on weak foundations (wrong macroeconomic policy) resulting later in the worst performance of the banking sector among all of the CEE countries and short term driven economic growth (personal and government consumption). This was followed by high unemployment rates in Croatia (among highest in the EU), top 2 highest long-term unemployment rates, among lowest activity and employment rates in the EU. Thus, overall financial policy supported consumption and not investments (particularly gross fixed capital investments) on the expense of the corporate sector and in favour of households. This is clearly visible from the structure of the total lending in Croatia in comparison to other CEE countries.

Table 3 shows that Poland, together with Croatia and Slovakia, has the highest share of loans to household in the GDP. Baltic countries register considerably lower share of loans to households in the GDP in comparison to the Balkan region and Central Europe. This is because of the still large market share in the hand of the state-owned banks (\% of total assets), which in 2016 amounted to $56 \%$ for Russia, 51\% for Ukraine, and 67\% for Belarus. In contrast, there is Croatia with 5.7\%, Czech Republic 2.4\%, Slovakia 0.8\%, Bulgaria 3.5\%, Bosnia and Hercegovina $1.7 \%$. State bank lending policy significantly differs from the foreign-owned banks. Another important aspect is the focus on the monetary policy. In CEE countries, central banks were generally oriented in maintaining monetary stability (low inflation and exchange rate-controlled volatility). Croatian central bank in an environment of macroeconomic instability pursued the policy of over appreciated exchange rate in terms of national currency. This, in turn, generated structural imbalances in the economy requiring tight monetary policy to compensate for the interest and exchange rate risks. In turn, high interest and exchange rate risks generate high systemic risk in the banking sector. In such environment, foreign owned banks in Croatia turn to excessive lending to households. Among the CEE countries and in the Eurozone, the share of household credits in the GDP is the highest in Croatia, even after the conversion of the Swiss franc loans and the crisis of 2008. The banking sector massively lending to households instead of private enterprises resulted in economic growth slowdown, structural imbalance, high unemployment and high level of private debt in relation to other CEE countries. The average share of household credits in the GDP in Poland is around 34\%, while the average share of Croatia is 37.5\%. Lending to household dynamics in both countries share a similar trend after 2010, with the exception that in the overall period massive lending to households in Croatia resulted in an over-leveraged economy. In an environment of over-leveraged economy, non-performing loans show high synchronization with unemployment dynamics in Croatia. Such trend is similar in Poland, however with a difference that share of the total loans in \% of GDP in Croatia in 2016 was $77.6 \%$, while in Poland it amounted to $54.6 \%$. Therefore, a strong bi-directional Granger cau- 
Table 3. Loans to Households and Private Enterprises (\% of GDP) 2012-2016 in selected CEE countries (source: Deuber, 2017)

\begin{tabular}{|c|c|c|c|c|c|}
\hline Country & 2012 & 2013 & 2014 & 2015 & 2016 \\
\hline \multicolumn{6}{|c|}{ Loans to Private Enterprises } \\
\hline Albania & 30.2 & 28.6 & 29.3 & 27.8 & 26.9 \\
\hline Bosnia and Hercegovina & 28.4 & 28.1 & 27.2 & 26 & 25.9 \\
\hline Belarus & 30.7 & 32.3 & 32.3 & 35.5 & 30.4 \\
\hline Bulgaria & 48.3 & 48.8 & 44.6 & 40.4 & 38.7 \\
\hline Croatia & 26.2 & 25.7 & 25.7 & 24.3 & 23 \\
\hline Czech Republic & 20.7 & 21.3 & 20.5 & 20.6 & 20.7 \\
\hline Hungary & 24.1 & 22.2 & 20.9 & 17.5 & 16.9 \\
\hline Poland & 17.1 & 17 & 17.5 & 18.2 & 18.5 \\
\hline Romania & 20.3 & 17.8 & 16 & 15.1 & 13.7 \\
\hline Russia & 32 & 34 & 41.6 & 40.1 & 37.6 \\
\hline Serbia & 29.9 & 25.2 & 24.3 & 24.1 & 22.9 \\
\hline Slovakia & 22.5 & 22.2 & 21.5 & 21.9 & 21.8 \\
\hline Slovenia & 53.3 & 39.3 & 30.6 & 26.7 & 23.6 \\
\hline Ukraine & 44.6 & 49.3 & 51 & 40.6 & 35.1 \\
\hline \multicolumn{6}{|c|}{ Loans to Households } \\
\hline Albania & 11.2 & 11 & 10.7 & 10.7 & 11.2 \\
\hline Bosnia and Hercegovina & 25.9 & 26.4 & 27.2 & 27.3 & 27.2 \\
\hline Belarus & 7.6 & 8.5 & 8.1 & 7.9 & 7.6 \\
\hline Bulgaria & 22.6 & 22.6 & 21.9 & 20.7 & 20.1 \\
\hline Croatia & 39.1 & 38.5 & 38.4 & 37.2 & 34.1 \\
\hline Czech Republic & 25.9 & 26.8 & 26.8 & 27.6 & 28.3 \\
\hline Hungary & 25.2 & 22.7 & 20.8 & 17.3 & 16.3 \\
\hline Poland & 33.4 & 34 & 34.1 & 35 & 35.6 \\
\hline Romania & 17.6 & 16.2 & 15.3 & 15.2 & 14.9 \\
\hline Russia & 12.4 & 15 & 16 & 12.9 & 13.5 \\
\hline Serbia & 18 & 17.2 & 18.5 & 18.7 & 19.3 \\
\hline Slovakia & 24.9 & 26.8 & 29.4 & 31.9 & 35.1 \\
\hline Slovenia & 26.3 & 24.8 & 23.9 & 23 & 23.1 \\
\hline Ukraine & 13 & 13 & 13 & 8.6 & 6.7 \\
\hline
\end{tabular}

sality relationship between lending and economic growth in both countries, however more prominent in the case of Croatia, is expected. Banks in Poland did not create the position of an over-leveraged economy due to the active role of the central bank and more flexible monetary policy. Bank lending policy favoring firm investments (particularly in the first stage of transition) followed by firm investments in capital equipment and not building and structures, led to the development of a strong, export oriented and competitive economy. An opposite scenario was present in other CEE countries. 


\section{Data and methodology}

This study considers Poland (as former transitional country) for the purpose of studying the impact of financial development and banks' lending on economic growth using time series econometric techniques with quarterly data from 1990-2018. The list of variables we use in the research:

- RGDP = Real GDP at constant national prices (in mil. 2011US\$) - Penn World Table 9.1. (2018).

- Rkna = Capital stock at constant national prices (in mil. 2011US\$) - Penn World Table 9.1.

- Emp = Number of persons engaged (in millions) - Penn World Table 9.1.

- Hc = Index of human capital per person, based on years of schooling and returns to education - Penn World Table 9.1.

- Tfp $=$ TFP at constant national prices $(2011=1)$ - Penn World Table 9.1.

- Trade $=$ Trade is the sum of exports and imports of goods and services measured as a share of gross domestic product (in \%) - World Bank, World Bank Indicators Database (World Bank, 2018c).

- Industry = Industry share in GDP (in \%) - World Bank, World Bank Indicators Database.

- Global = KOF index of globalization - Gygli, Haelg \& Sturm (2018)

- Invm = Gross fixed investments in machinery and equipment in \% of total gross fixed investments - WIIW Annual Database (2018).

Financial development proxies are listed below:

- Credit $=$ Private credit by deposit money banks and other financial institutions to GDP (in \%) - Financial development and structure dataset, Global financial development database (June 2018) (World Bank, 2018 a, 2018b).

- Stockc $=$ Stock market capitalization to GDP (in \%) - Financial development and structure dataset, Global financial development database (June 2018).

- Stockv = Stock market total value traded to GDP (in \%) - Financial development and structure dataset, Global financial development database (June 2018).

- Margin = Banks net interest margin (in \%) - Financial development and structure dataset, Global financial development database (June 2018).

- Spread = Bank lending-deposit spread (in \%) - Financial development and structure dataset, Global financial development database (June 2018).

- $\mathrm{ROA}=$ Bank return on assets (in \% after tax) - Financial development and structure dataset, Global financial development database (June 2018).

- $\mathrm{ROE}=$ Bank return on equity (in \% after tax) - Financial development and structure dataset, Global financial development database (June 2018).

- Turnover $=$ Stock market turnover ratio (in \%) - Financial development and structure dataset, Global financial development database (June 2018).

- Z score = Bank Z-score Financial development and structure dataset, Global financial development database (June 2018).

- Households1 = Household credit share in GDP (in \%) - Florian Léon (2018a), The Credit Structure Database (June 2018). 
- Firms1 = Firms credit share in GDP (in \%) - Florian Léon (2018a), The Credit Structure Database.

- Households2 = Households credit share in total credits (in \%) - Bank for International Settlements (BIS) database (June 2018).

- Firms2 = Firms credit share in total credits (in \%) - Bank for International Settlements (BIS) database.

Since long time series financial data are not available on the quarterly basis and this is particularly true for macroeconomic data we use in this analysis we use annual data transformed using standard frequency conversion approach (low to high - quadratic match average in Eviews 10). The data were obtained from several databases: Penn World Table 9.1 (Feenstra, Inklaar, \& Timmer, 2015), World Bank, World Bank Indicators Database (2018c), Gygli et al. (2018), Financial development and structure dataset (Beck, Demirgüç-Kunt, \& Levine, 2000, 2009; Cihák, Demirguc-Kunt, Feyen, \& Levine, 2012), Global financial development database (Cihák et al., 2012; Léon, 2018a), WIIW annual database. The Credit Structure Database and BIS database for Poland, KNF-Polish Financial Supervision Authority database (KNF, June 2018).

Plots of the variable's series (not presented here) suggests that data are non-stationary in level and stationary in the first difference. Variables also exhibit a trend pattern pointing to a possible cointegrational relationship. First, we test for the stationarity in the series using standard unit root test; (ADF) - Dickey and Fuller (1979), (PP) - Phillips and Perron (1988), and (KPSS) - Kwiatkowski, Phillips, Schmidt and Shin (1992).

From Table 4 we can see that the battery of standard unit root test results show series to be integrated of order 1 , that is, $\mathrm{I}(1)$. Results of the stationarity test show that all the variables are non-stationary in level and stationary in difference. Since all the variables are integrated we look for a possible cointegration relationship between the selected variables for Poland and apply the Johansen cointegration test (Johansen, 1991, 1995), (Johansen \& Juselius, 1990). Using standard VAR (vector autoregression) lag selection procedure based on (AIC) - Akaike's (Akaike, 1974) and (SIC) - Schwarz's Information Criteria (Schwarz, 1978). To investigate the impact of credits on economic growth we use the model:

$$
R G D P=\beta_{0}+\beta_{1} T f p_{1}+\beta_{2} H c_{t}+\beta_{3} \text { Global }_{t}+\beta_{4} F D_{t}+e_{t},
$$

where $R G D P, T f p, H c, F D$ (represent a set of the proxy variables for the financial development as defined in the methodology section) and $e_{t}=$ stationary disturbance term. All variables (series) in the Eq. (1) are in the expressed in logarithm form (we read them as partial elasticity coefficients). To select the optimum lag length (since cointegration models are sensitive to the number of lags) we estimate a vector error correction autoregression model (VECM) of (1) in the form:

$$
\begin{aligned}
& \Delta R G D P_{1 t}=\mu_{1 t}-\phi_{1}\left(R G D P-\gamma_{0}-\gamma_{1} T f p-\gamma_{2} H c-\gamma_{3} \text { Global }-\gamma_{4} F D\right)_{t-1}+ \\
& \sum_{i=1}^{j} \beta_{1, j} \Delta R G D P_{1-i}+\sum_{i=1}^{j} \beta_{2, j} \Delta T f p_{1-i}+\sum_{i=1}^{j} \beta_{3, j} \Delta H c_{11-i}+\sum_{i=1}^{j} \beta_{4, j} \Delta G l o b a l_{1-i}+\sum_{i=1}^{j} \beta_{5, j} \Delta F D_{1-i}+\varepsilon_{1 t} .
\end{aligned}
$$


Table 4. Unit Root Test Results (source: Authors' calculations)

\begin{tabular}{|c|c|c|c|c|c|c|}
\hline \multirow[t]{2}{*}{ Series } & $\begin{array}{c}\mathrm{ADF} \\
\text { (trend and } \\
\text { intercept) }\end{array}$ & $\begin{array}{c}\mathrm{ADF} \\
\text { (trend and } \\
\text { intercept) }\end{array}$ & $\begin{array}{c}\mathrm{PP} \\
\text { (trend and } \\
\text { intercept) }\end{array}$ & $\begin{array}{c}\mathrm{PP} \\
\text { (trend and } \\
\text { intercept) }\end{array}$ & $\begin{array}{c}\text { KPSS } \\
\text { (trend and } \\
\text { intercept) }\end{array}$ & $\begin{array}{c}\text { KPSS } \\
\text { (trend and } \\
\text { intercept) }\end{array}$ \\
\hline & Level & $\begin{array}{c}\text { First } \\
\text { difference }\end{array}$ & Level & $\begin{array}{c}\text { First } \\
\text { difference }\end{array}$ & Level & $\begin{array}{c}\text { First } \\
\text { difference }\end{array}$ \\
\hline RGDP & -0.9579 & $-4.1382^{\star *}$ & -1.1595 & $-4.1826^{* *}$ & $0.1579^{* *}$ & 0.075 \\
\hline Rkna & 0.7011 & $-3.344^{\star}$ & 0.1977 & -1.2900 & $0.2974^{\star * *}$ & 0.074 \\
\hline Emp & -1.4472 & $-3.8764^{* *}$ & -2.6113 & $-3.8764^{* *}$ & $0.2394^{\star \star \star}$ & 0.0700 \\
\hline $\mathrm{Hc}$ & -0.7124 & 0.3226 & 0.1023 & $-4.2056^{\star * *}$ & $0.1377^{\star}$ & $0.2053^{\star \star}$ \\
\hline Tfp & -2.8351 & -2.0896 & -1.4739 & $-3.6626^{* *}$ & 0.0982 & 0.1150 \\
\hline Trade & -3.1189 & $-5.5789^{* * *}$ & $-3.1941^{\star}$ & $-5.5501^{\star * *}$ & 0.0744 & 0.0252 \\
\hline Industry & -1.0459 & $-2.9042^{* * *}$ & $-2.3878^{\star *}$ & $-3.2274^{\star * *}$ & $0.6797^{\star *}$ & $0.4910^{*}$ \\
\hline Global & -1.4958 & -2.8496 & -0.6934 & $-6.0251^{\star * *}$ & $0.2860^{* *}$ & 0.0633 \\
\hline Invm & -3.0380 & $-4.0569^{* * *}$ & -1.7044 & $-5.0608^{\star * *}$ & $0.1758^{\star *}$ & 0.1022 \\
\hline Credit & $-3.6708^{\star *}$ & $-3.5291^{\star *}$ & -1.7682 & $-3.5919^{\star *}$ & $0.1885^{\text {** }}$ & 0.0924 \\
\hline Stockc & -2.6929 & -2.5013 & -2.4131 & $-4.6176^{\star * \star}$ & $0.1739^{* *}$ & 0.044 \\
\hline Stockv & 0.0839 & $-2.4591^{* *}$ & -2.4104 & $-4.3694^{* * *}$ & $0.9577^{\star *}$ & 0.0392 \\
\hline Margin & -2.4654 & $-3.5336^{\star * *}$ & $-3.5466^{\star *}$ & $-5.7187^{\star * *}$ & $0.8395^{\star * *}$ & 0.1451 \\
\hline Spread & -1.4083 & $-2.4229^{\star *}$ & $-3.5602^{\star *}$ & $-4.6749^{* * *}$ & $0.2169^{* * *}$ & 0.1173 \\
\hline $\mathrm{ROA}$ & -2.8963 & $-3.0581^{* * *}$ & -3.0802 & $-5.6343^{* * *}$ & 0.0808 & 0.0343 \\
\hline $\mathrm{ROE}$ & $-2.8094^{*}$ & $-3.256^{* *}$ & -3.0283 & $-5.6691^{\star * *}$ & $0.1917^{\text {** }}$ & 0.0325 \\
\hline Turnover & -2.2562 & $-4.6051^{\star * *}$ & -2.6195 & $-5.5013^{* * *}$ & $0.2086^{\star *}$ & 0.070 \\
\hline Z-score & -0.2530 & $-3.0709^{* * *}$ & $-3.2212^{\star}$ & $-5.5951^{\star * *}$ & $0.1874^{\star *}$ & 0.0373 \\
\hline Households1 & -3.1247 & $-3.5032^{\star *}$ & -1.5484 & $-3.4907^{\star *}$ & $0.1631^{\star *}$ & 0.0928 \\
\hline Firms1 & -2.6625 & $-4.1350^{* * *}$ & -2.2975 & $-4.1350^{* * *}$ & $0.1812^{* *}$ & 0.0611 \\
\hline Households2 & -1.0545 & $-3.1527^{\star *}$ & -0.4569 & $-4.1173^{\star * *}$ & $0.2538^{\star * *}$ & 0.1123 \\
\hline Firms2 & -1.0544 & $-3.1528^{\star *}$ & -0.4584 & $-4.1166^{* * *}$ & $0.2532^{\star * *}$ & 0.1124 \\
\hline
\end{tabular}

Note: ${ }^{* * *},{ }^{* *}$ and ${ }^{*}$ denote significance at $1 \%, 5 \%$ and $10 \%$ respectively. Maximum lag length for the test was selected based on the lag length criteria (lag length test) considering loss in the degrees of freedom.

Checking the autocorrelation of the error terms in each of the VECM using Ljung-Box Q statistics (Ljung \& Box, 1978) we repeat the test by increasing one lag until regression error term show no autocorrelation issue (optimum lag). Optimum lag selection is also tested by using (AIC) and (SIC) in the Wald Lag exclusion test (Lütkepohl, 2005). Both test, (Ljung \& Box, 1978) and Wald test (Lütkepohl, 2005) select the lag lenght of 9 as optimum lag length in the VECM. Table 5 show the results for the Johansen and Juselius (1990) cointegration test.

Test results (Table 5) show that both Trace test and Max-Eigen test are statistically significant in rejecting the null hypothesis of no cointegrating relations between the variables at $5 \%$ significance level. Trace and Max-Eigen test fail to reject the null of one (1) cointegrating equation at 5\% significance level finding one long run cointegration relationship between RGDP and its determinants in the Eq. (1). This holds for the FD with Credit as proxy as long for Household 2 and Firms 2 series. Therefore, based on the unit root test results and Johansen-Juselius cointegration test we proceed with the VECM including Credit, Household2 and Firms2 as proxies for financial development in Poland. 
Table 5. Johansen-Juselius cointegration test results (source: authors' calculation)

\begin{tabular}{|c|c|c|c|c|c|}
\hline \multirow{2}{*}{$\begin{array}{l}\text { Hypothesized number } \\
\text { of cointegrating relations }\end{array}$} & \multirow{2}{*}{$\begin{array}{c}\text { Trace } \\
\text { Statistics }\end{array}$} & \multirow{2}{*}{$\frac{\text { Max-Eigen }}{\text { Statistics }}$} & \multicolumn{2}{|c|}{ Critical Values (5\%) } & \multirow[t]{2}{*}{ FD variable } \\
\hline & & & Trace & Max-Eigen & \\
\hline & & & & & Credit \\
\hline $\mathrm{r}=0$ & $103.77^{\star \star}$ & $41.08^{\star \star}$ & 88.80 & 38.33 & \\
\hline \multirow[t]{2}{*}{$\mathrm{r} \leq 1$} & 62.68 & 28.55 & 63.87 & 32.11 & \\
\hline & & & & & Stockc \\
\hline $\mathrm{r}=0$ & $170.56^{\star *}$ & $89.78^{\star \star}$ & 69.81 & 33.87 & \\
\hline $\mathrm{r} \leq 1$ & $80.78^{\star \star}$ & $53.46^{\star *}$ & 47.85 & 27.58 & \\
\hline \multirow[t]{2}{*}{$r \leq 2$} & 27.31 & 20.36 & 29.79 & 21.13 & \\
\hline & & & & & Stockv \\
\hline$r=0$ & $157.24^{\star \star}$ & $80.15^{\star \star}$ & 69.81 & 33.87 & \\
\hline $\mathrm{r} \leq 1$ & $77.08^{\star \star}$ & $45.91^{\star \star}$ & 47.85 & 27.58 & \\
\hline \multirow[t]{2}{*}{$r \leq 2$} & 21.17 & 14.90 & 29.79 & 21.13 & \\
\hline & & & & & Margin \\
\hline$r=0$ & $199.89^{* *}$ & $105.29^{* *}$ & 69.81 & 33.87 & \\
\hline $\mathrm{r} \leq 1$ & $94.59^{* *}$ & $61.16^{* *}$ & 47.85 & 27.58 & \\
\hline $\mathrm{r} \leq 2$ & $33.42^{\star \star}$ & $21.81^{\star \star}$ & 29.79 & 21.13 & \\
\hline \multirow[t]{2}{*}{$\mathrm{r} \leq 3$} & 11.61 & 7.70 & 15.49 & 14.26 & \\
\hline & & & & & Spread \\
\hline $\mathrm{r}=0$ & $147.83^{\star *}$ & $82.53^{\star \star}$ & 69.81 & 33.87 & \\
\hline $\mathrm{r} \leq 1$ & $65.29^{* *}$ & $40.20^{\star *}$ & 47.85 & 27.58 & \\
\hline \multirow[t]{2}{*}{$\mathrm{r} \leq 2$} & 25.09 & 21.40 & 29.79 & 21.13 & \\
\hline & & & & & ROA \\
\hline $\mathrm{r}=0$ & $136.00^{* *}$ & $57.68^{\star *}$ & 69.81 & 33.87 & \\
\hline $\mathrm{r} \leq 1$ & $78.31^{\star *}$ & $32.20^{* *}$ & 47.85 & 27.58 & \\
\hline $\mathrm{r} \leq 2$ & $46.11^{\star \star}$ & $28.15^{\star *}$ & 29.79 & 21.13 & \\
\hline $\mathrm{r} \leq 3$ & $17.96^{\star *}$ & $17.26^{\star *}$ & 15.49 & 14.26 & \\
\hline \multirow[t]{2}{*}{$\mathrm{r} \leq 4$} & 0.699 & 0.699 & 3.84 & 3.84 & \\
\hline & & & & & ROE \\
\hline$r=0$ & $130.38^{\star *}$ & $55.74^{\star *}$ & 69.81 & 33.87 & \\
\hline $\mathrm{r} \leq 1$ & $74.63^{* *}$ & $30.84^{* *}$ & 47.85 & 27.58 & \\
\hline $\mathrm{r} \leq 2$ & $43.78^{\star \star}$ & $27.39^{\star *}$ & 29.79 & 21.13 & \\
\hline$r \leq 3$ & $16.39^{* *}$ & $15.70^{\star *}$ & 15.49 & 14.26 & \\
\hline \multirow[t]{2}{*}{$\mathrm{r} \leq 4$} & 0.68 & 0.68 & 3.84 & 3.84 & \\
\hline & & & & & Turnover \\
\hline$r=0$ & $180.44^{\star}$ & $77.02^{\star *}$ & 69.81 & 33.87 & \\
\hline $\mathrm{r} \leq 1$ & $103.42^{* *}$ & $61.16^{\star *}$ & 47.85 & 27.58 & \\
\hline $\mathrm{r} \leq 2$ & $42.25^{\star *}$ & $29.51^{\star *}$ & 29.79 & 21.13 & \\
\hline \multirow[t]{2}{*}{$\mathrm{r} \leq 3$} & 12.73 & $12.70^{\star *}$ & 15.49 & 14.26 & \\
\hline & & & & & Z score \\
\hline
\end{tabular}


End of Table 5

\begin{tabular}{|c|c|c|c|c|c|}
\hline \multirow{2}{*}{$\begin{array}{l}\text { Hypothesized number } \\
\text { of cointegrating relations }\end{array}$} & \multirow{2}{*}{$\begin{array}{c}\text { Trace } \\
\text { Statistics }\end{array}$} & \multirow{2}{*}{$\frac{\text { Max-Eigen }}{\text { Statistics }}$} & \multicolumn{2}{|c|}{ Critical Values (5\%) } & \multirow[t]{2}{*}{ FD variable } \\
\hline & & & Trace & Max-Eigen & \\
\hline$r=0$ & $159.88^{\star *}$ & $62.37^{\star \star}$ & 69.81 & 33.87 & \\
\hline $\mathrm{r} \leq 1$ & $97.50^{* *}$ & $44.20^{\star *}$ & 47.85 & 27.58 & \\
\hline$r \leq 2$ & $53.28^{\star *}$ & $39.67^{\star *}$ & 29.79 & 21.13 & \\
\hline \multirow[t]{2}{*}{$\mathrm{r} \leq 3$} & 13.62 & 13.57 & 15.49 & 14.26 & \\
\hline & & & & & Households1 \\
\hline$r=0$ & $188.71^{\star \star}$ & $106.15^{\star \star}$ & 69.81 & 33.87 & \\
\hline $\mathrm{r} \leq 1$ & $82.56^{\star \star}$ & $43.20^{\star *}$ & 47.85 & 27.58 & \\
\hline $\mathrm{r} \leq 2$ & $39.36^{\star *}$ & $20.75^{\star \star}$ & 29.79 & 21.13 & \\
\hline$r \leq 3$ & $18.61^{\star *}$ & $17.93^{\star *}$ & 15.49 & 14.26 & \\
\hline \multirow{2}{*}{$\mathrm{r} \leq 4$} & 0.67 & 0.67 & 3.84 & 3.84 & \\
\hline & & & & & Firms1 \\
\hline$r=0$ & $187.70^{\star *}$ & $88.92^{\star *}$ & 69.81 & 33.87 & \\
\hline $\mathrm{r} \leq 1$ & $98.77^{\star *}$ & $40.23^{\star *}$ & 47.85 & 27.58 & \\
\hline $\mathrm{r} \leq 2$ & $58.54^{\star \star}$ & $39.60^{* *}$ & 29.79 & 21.13 & \\
\hline$r \leq 3$ & $18.94^{\star *}$ & $18.42^{\star *}$ & 15.49 & 14.26 & \\
\hline \multirow[t]{2}{*}{$\mathrm{r} \leq 4$} & 0.51 & 0.51 & 3.84 & 3.84 & \\
\hline & & & & & Households2 \\
\hline$r=0$ & $97.26^{\star \star}$ & $49.72^{\star \star}$ & 69.81 & 33.87 & \\
\hline \multirow[t]{2}{*}{$\mathrm{r} \leq 1$} & 47.54 & 26.54 & 47.85 & 27.58 & \\
\hline & & & & & Firms2 \\
\hline$r=0$ & $96.52^{\star *}$ & $55.87^{\star *}$ & 69.81 & 33.87 & \\
\hline $\mathrm{r} \leq 1$ & 42.12 & 26.71 & 47.85 & 27.58 & \\
\hline
\end{tabular}

Note: ${ }^{\star *}$ denote significant at $5 \%$ significance level.

\section{Results}

The estimated VECM for Poland takes the form of the long run Eq. (3) after normalization $\operatorname{LnRGDP}_{t-1}=1.8874+11.1697 \operatorname{LnTpf}_{t-1}+6.8623 \operatorname{LnHc}_{t-1}+0.7081$ LnGlobal $_{t-1}+0.3703$ LnCredit $_{t-1}$
(std. er.)
$(0.5757)$
(0.5312)
(0.3085)
(0.0559)
(t-stat)
[19.4002]
[12.9268]
[2.2954]
[6.6225].

All variables in the Eq. (3) are positively significant at 5\% significance level. Estimated VECM show the long run equilibrium relationship between real GDP (output), total factor productivity, human capital stock, level of country's exposure to globalization and bank lending. Since all variables are expressed in the logarithm form, associated long run parameters can be interpreted as partial elasticity coefficients. We can observe that a $1 \%$ increase in total factor productivity (Tfp) rise Poland's real GDP by $11 \%$. Similar positive and large effect on GDP we register for the increase in the human capital stock $(\mathrm{Hc})$ with $1 \%$ increase in the human capital stock leading to $6.8 \%$ increase in the real GDP. Globalization level has also 
positive effect on the Poland's real GDP with $1 \%$ increase in the KOF index (Global) resulting in real GDP increase of $0.71 \%$. Lending activity of the financial sector measured by the share of total credits in the GDP also has positive impact on the real output in Poland. An increase in the bank lending activity measured by (Credit) of $1 \%$ leads to a growth in the real GDP by $0.37 \%$. The results are consistent and within reasonable bounds in accordance with the theory.

Equation (3) show the long run impact of selected variables on the real GDP in Poland over 1990-2018. To estimate the short run impact, we use the Granger causality test (Granger, 1969). Granger causality test results together with the error correction terms - speed of adjustment coefficients (loading matrix) are visible in the Table 6.

Table 6. Granger causality results from VECM (source: authors' calculation)

\begin{tabular}{|c|c|c|c|c|c|c|}
\hline \multicolumn{7}{|c|}{ Independent variable } \\
\hline \multirow[b]{2}{*}{$\begin{array}{l}\text { Dependent } \\
\text { variable }\end{array}$} & \multicolumn{5}{|c|}{$\chi^{2}$ statistics of lagged $1^{\text {st }}$ differenced term [p-value] } & \multirow{2}{*}{$\begin{array}{l}\text { ECT coefficient } \\
\text { (t-ratio) }\end{array}$} \\
\hline & $\Delta \operatorname{lnRGDP}$ & $\Delta$ LnTfp & $\Delta \mathrm{LnHc}$ & $\begin{array}{l}\Delta \text { Ln } \\
\text { Global }\end{array}$ & $\begin{array}{l}\Delta \text { Ln } \\
\text { Credit }\end{array}$ & \\
\hline$\Delta \ln R G D P$ & - & $\begin{array}{c}31.99 \\
{[0.000]^{* * *}}\end{array}$ & $\begin{array}{c}25.13 \\
{[0.002]^{* * *}}\end{array}$ & $\begin{array}{c}11.60 \\
{[0.236]}\end{array}$ & $\begin{array}{c}23.78 \\
{[0.004]} \\
\end{array}$ & $\begin{array}{c}-0.1502 \\
(-3.233)^{\star \star} \\
\end{array}$ \\
\hline$\Delta$ LnTfp & $\begin{array}{c}146.65 \\
{[0.000]^{\star * *}}\end{array}$ & - & $\begin{array}{c}22.52 \\
{[0.007]^{* * *}}\end{array}$ & $\begin{array}{c}60.14 \\
{[0.000]^{\star * *}}\end{array}$ & $\begin{array}{c}19.68 \\
{[0.019]^{\star \star}}\end{array}$ & $\begin{array}{c}-0.074 \\
(10.835)^{\star \star \star}\end{array}$ \\
\hline$\Delta \mathrm{LnHc}$ & $\begin{array}{c}11.32 \\
{[0.254]}\end{array}$ & $\begin{array}{c}3.924 \\
{[0.916]}\end{array}$ & - & $\begin{array}{c}0.837 \\
{[0.997]}\end{array}$ & $\begin{array}{c}2.353 \\
{[0.984]}\end{array}$ & $\begin{array}{c}0.0015 \\
(2.221)^{\star *}\end{array}$ \\
\hline $\begin{array}{l}\Delta \text { Ln } \\
\text { Global }\end{array}$ & $\begin{array}{c}25.75 \\
{[0.000]^{* * *}}\end{array}$ & $\begin{array}{c}2.976 \\
{[0.965]}\end{array}$ & $\begin{array}{c}1.858 \\
{[0.993]}\end{array}$ & - & $\begin{array}{c}6.465 \\
{[0.692]} \\
\end{array}$ & $\begin{array}{l}0.0184 \\
(1.317) \\
\end{array}$ \\
\hline $\begin{array}{l}\Delta \text { Ln } \\
\text { Credit }\end{array}$ & $\begin{array}{c}56.81 \\
{[0.000]^{* * *}}\end{array}$ & $\begin{array}{c}14.29 \\
{[0.112]}\end{array}$ & $\begin{array}{c}10.97 \\
{[0.277]}\end{array}$ & $\begin{array}{c}8.513 \\
{[0.483]} \\
\end{array}$ & - & $\begin{array}{c}-0.074 \\
(-2.665)^{* *} \\
\end{array}$ \\
\hline
\end{tabular}

Note: ${ }^{* *}$ and ${ }^{* *}$ denotes significant at $1 \%$ and $5 \%$ significance level, respectively. The number in the parenthesis (...) denote as t-statistic and in the squared brackets [...] represent a p-value.

All speed of adjustment coefficients are statistically significant except for the globalization (Global) parameter. Most of the adjustment in the real GDP for Poland is achieved by the adjustment in the past real GDP values (15\%), adjusting changes in the total factor productivity (7\%) and lending activity (7\%). Human capital stock do not show important adjustment properties in the short run which is expected since the nature of the educational process (lagged returns to education). The same holds for globalization. Granger causality test results show a bidirectional causality running between lending activities (Credits) and output $(R G D P)$. We find the finance-growth nexus to bilaterally support demand-leading (economic growth lead to higher financial development) and supply-leading (financial development leads to higher output growth) hypothesis. Increase in the lending activities leads to increase in the total factor productivity, export competitiveness and favorable balance account position. We also find the credit structure to be important factor of growth in Poland. In fact, a $1 \%$ increase in financial lending to firms (Firms2) result in a real GDP increase of $1.66 \%$ while $1 \%$ increase in household lending (Household2) gives rise to output by $1.47 \%$. 
Variance decomposition (see Figure 3) show the impact of variations in total factor productivity, human capital, globalization and credit activity on the real GDP.

From the Figure 3 we can see that most of the changes in the RGDP dynamics can be explained by changes (current and future innovation) in the output itself and human capital. Past output level (starting level of real GDP) has the largest impact on current and future values of real GDP in Poland which is in accordance with most growth econometric studies. Innovation impact on future output dynamics diminish with time (from $100 \%$ in first quarter to $50 \%$ after ten quarters). The impact of human capital innovation on output dynamics is small after the first quarter but in the long run it becomes significant (more than $30 \%$ after ten quarters). Forecast variance for the RGDP of the innovation in total factor productivity, globalization and credit activity is positive ranging from $2 \%$ to $5 \%$ changes in the real GDP. When we use the Credit variable as proxy for the FD in the VECM, the assessed impact of the lending activity on the real GDP in Poland is positive but limited. There is a positive impact of financial development on economic growth in Poland but on a limited scale. Same results hold for the impulse response analysis from the VECM (3).

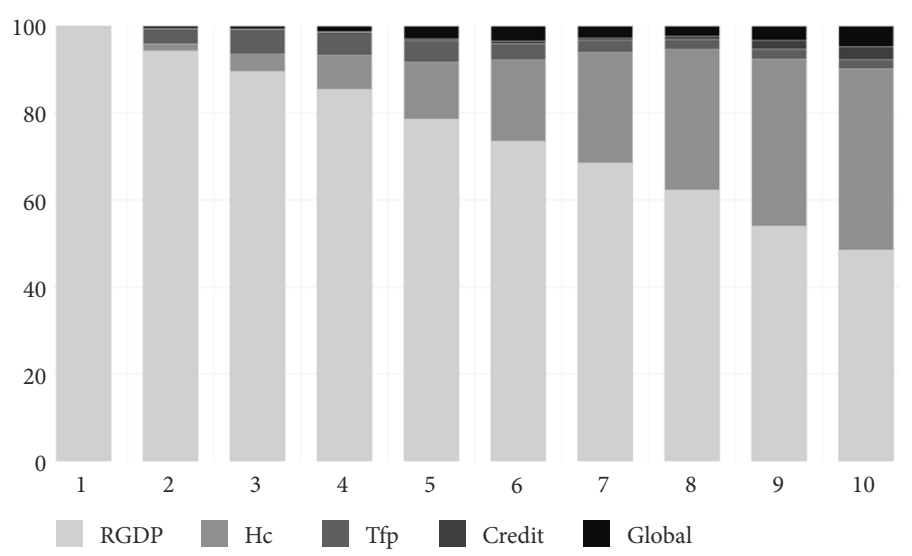

Figure 3. Variance decomposition of RGDP (with Credit) (source: authors' calculations)

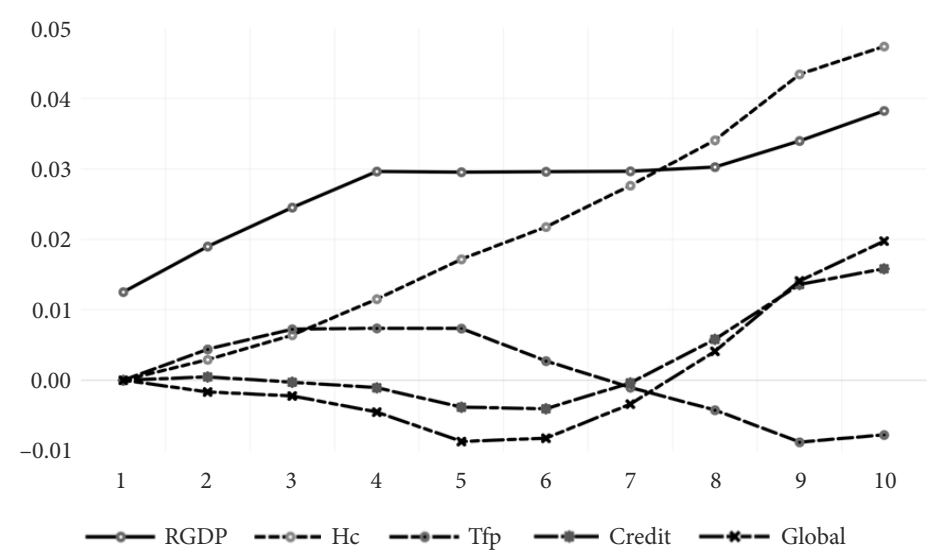

Figure 4. Response of RGDP to innovation (Shocks) (with Credit) (source: authors' calculations) 
Figure 4 confirms the results obtained by the real GDP variance decomposition (Cholesky one standard deviation innovation on $y$ axis and time - quarters on $x$ axis). Innovation (shock) in output has positive, long lasting impact on the real GDP (over ten quarters). We can see that the effects of the shock in the real GDP is not dying out in the long run showing long memory properties. Same holds for the exogenous shock in the human capital stock with the innovation lasting over ten quarters. Changes (shock) in the total factor productivity have positive effect on RGDP up to seven (7) quarters converging to zero becoming negative in the long run (Baumol's cost disease and great decoupling paradox). Shock in Credit has neutral effect on the real GDP up to four quarters turning negative up to the seven quarters. After seven quarters banks' lending start to have positive effects on the real GDP dynamics and the effects stay in place over the long run (beyond ten quarters). The same dynamics as for Credit is visible for Global, that is, globalization has positive effect on the GDP dynamics in Poland over the long run.

To study the impact of the credit structure using Firms 2 as proxy variable for FD in the model we use VECM of the form:

$\begin{array}{lcccc}\begin{array}{l}\text { LnRGDP } \\ \text { (std. er. }\end{array}=13.74+7.80234 \operatorname{LnTpf}_{t-1}+6.8623 \operatorname{LnHc}_{t-1}+3.8683 \text { LnGlobal }_{t-1}+1.6668 \text { LnFirms }_{t-1} \\ \text { (t-stat) } & (3.17497) & (24.39263) & (1.61819) & (0.53546) \\ \end{array}$

We can see that models' results are quite different when using (Firms2) firms credit share (in \%) in private credit by deposit money banks and other financial institutions. This indicator gives more realistic view on the real impact of financial development on economic growth. Using this indicator, the assessed impact of bank lending on economic growth in Poland is twofold higher in respect to the one assessed when using total credit share in the GDP indicator as proxy for financial development. Also, we can notice that the impact of increase in total factor productivity and human capital stock have larger effects on output in relation to the Eq. (3). This is because firms in Poland used bank lending to invest in machinery and equipment, in fact over 1990-2018 average gross fixed investments in machinery and equipment in total investments was $42.5 \%$. Every second Euro of bank credit was invested in machinery and equipment leading to increase in total factor productivity and human capital stock finally rising the output in Poland. Figure 5 support this thesis.

From the Figure 5 we can see output dynamics in Poland can be explained by variations in the starting level of real GDP, human capital, banks' lending to firms and increase in the total factor productivity. Thus, when using disaggregated data on bank lending, in this case, bank lending to firms, we can observe that bank lending exercise more impact on output then before. We can also see the long run relationship that exists between financial development and economic growth in Poland and now the nexus between them is much stronger and larger. Same results hold for the impulse response function of Eq. (4).

We can see on the Figure 6 that innovations (shocks) in real GDP, human capital, bank lending to firms and globalization have long term positive impact on the output dynamics in Poland. Shock to total factor productivity in the short run has positive impact on output but in the long run as sectors with growing productivity catch up with the Baumol's cost disease (Baumol \& Bowen, 1966). Wages in the sectors with growing productivity rush up wages in 
other sectors with stagnating labour productivity - education and health care. This in turn demands large government spending to cover up the costs of the Baumol's disease trailing down total factor productivity and output in the long run. The impact of innovation in the human capital stock on the real output is the largest since wages for skilled labor in the IT and other growing productivity sectors go up pulling up personal consumption expenditures. The effect of a change in the human capital stock is positive and show long memory properties. A shock to Firms2 has positive and long-lasting effects on the real GDP with the effect continuing to persist beyond the $10^{\text {th }}$ quarter. Global share the same dynamics since firms' use bank lending and improve capital/output ratio resulting in a rise in competitive export and share in the world trade.

To study the impact of the credit structure using Households 2 as proxy variable for FD in the model we use VECM of the form:

$$
\begin{array}{lcccc}
\text { LnRGDP }_{t-1}=11.05+3.5346 \text { LnTpf }_{t-1}+3.2780 \text { LnHc }_{t-1}+2.1367 \text { Ln Global }_{t-1}+1.4737 \text { LnHouseholds }_{t-1} \\
\text { (std. er.) } & (5.39271) & (3.55081) & (2.35343) & (0.35586) \\
\text { (t-stat) } & {[-19.5699]} & {[-11.0617]} & {[3.88230]} & {[-4.14137] .}
\end{array}
$$

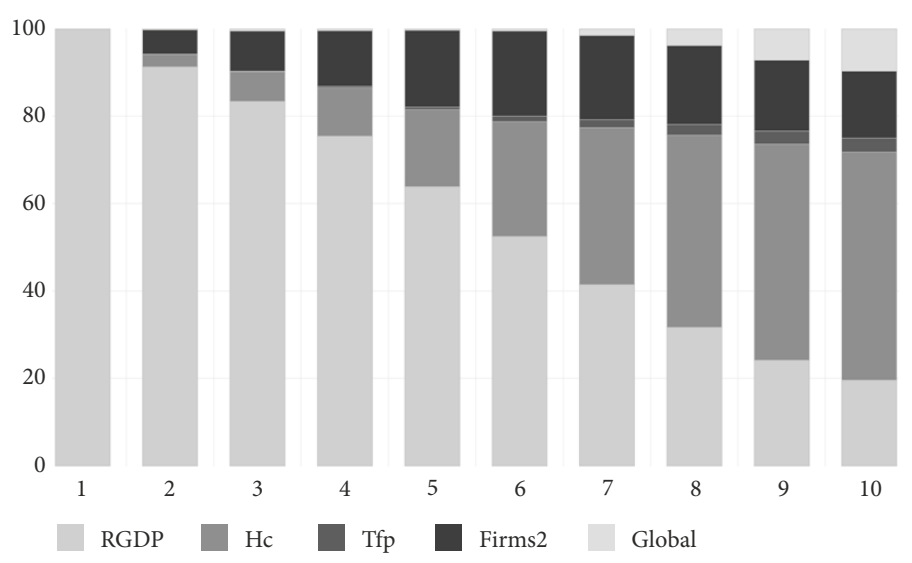

Figure 5. Variance decomposition of RGDP (with Firms2) (source: authors' calculations)

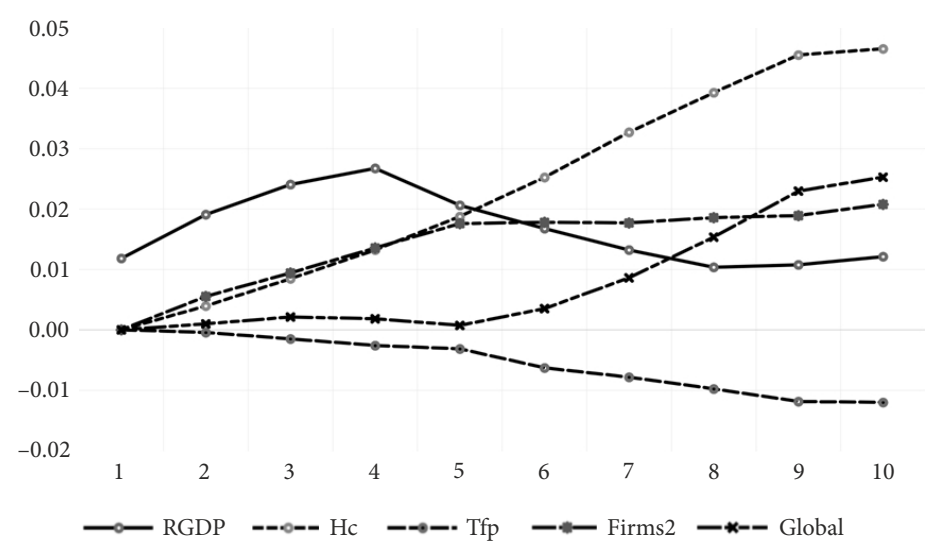

Figure 6. Response of RGDP to innovation (Shocks) (with Firms2) (source: authors' calculations) 
As in the previous models (3) and (4), a long run relationship between financial development measured by household credit share (in \%) in private credit by deposit money banks and other financial institutions (Households2). Households lending has positive effect on the real GDP through mortgage lending pushing up productivity and value added in the construction sector. Households lending in relation to the firms lending has less impact on the real GDP since the implied effect on the total factor productivity (Tfp) is lower as well on the human capital stock $(\mathrm{Hc})$ and globalization (Global). Long run effects of households lending are positive but not so prominent as in the case of firms lending. Variance decomposition in the Figure 7 show the effects of the households lending on the real GDP.

Previous level of real GDP, human capital stock and households' credits contribute to over $70 \%$ of the real GDP forecast error variance for Poland. Changes in the real GDP for Poland to a large extent can be attributable to changes in the real GDP, human capital and household lending. In the short run, up to seven quarters, majority of the change in the real GDP dynamics is attributed to the change in the real GDP itself. In the long run, however, this impact slows down declining to $30 \%$ of the forecast error variance over ten quarters. Human capital stock do not affect real GDP forecast error variance in the short run which is expected since educational returns show long memory properties. In the long run human capital stock exert large effects on the real GDP forecast error variance around 35\% almost the same as household lending. Thus, in the short run forecast error variance of the real GDP is dominated by shocks in the real GDP. In the medium run (5-6 quarters) forecast error variance for real GDP is attributable to shocks in the real GDP and household lending. In the long run (7-10 quarters) shocks to household lending, human capital stock and the real GDP dominate over other selected variables. These results are confirmed by the impulse response analysis of the VECM (5).

Shocks (innovation) to household lending and total factor productivity (see Figure 8) show prolonged negative effects on the real GDP in the long run. Following a one standard deviation shock to the Tfp and Households2, real GDP in Poland decline immediately (after two quarters) and sharply (after five quarters). High non-performing loans share (non-performing loans in \%) in Poland may explain this strong sensitivity of real GDP and total factor productivity to household lending. High level of non-performing loans intensifies credit constraints causing decline in total factor productivity and output. In response to a one standard deviation shock (increase) to the human capital stock, the real GDP rises rapidly in Poland. Same holds for the globalization impact on the real GDP and shocks to RGDP. The impulse response analysis of the VECM (5) of one standard deviation shocks (innovation) in the $R G D P, H c$ and Global move the output in Poland to a new equilibrium, higher in relation to the previous one. Shocks in Tfp and Households2 move the real GDP to a new equilibrium level lower than the previous.

\section{Discussion of results}

The error correction models (VECM), forecast variance decomposition and impulse response analysis show a strong and positive nexus between financial development (bank lending) and economic growth in Poland. Total factor productivity, human capital stock, globalization and bank lending show positive relationship with the real GDP in the long run. Adjustment 
coefficients are statistically significant finding a deviation from the long run relationship between real GDP and Tfp, Hc, FD, Global is promptly restored to a new equilibrium by adjustment of the same variables. The obtained results are in line with the results obtained by Katircioglu, Kahyalar and Benar (2007) that confirm the existence of a bidirectional causality between financial development, which was measured by financial sector lending activity, and economic growth in Poland. The same results were also obtained in the studies by Bangake and Eggoh (2011), Levine, Loayza and Beck (2000), Carby, Craigwell, Wright and Wood (2012), Shan and Jianhong (2006), Odhiambo (2005) and Maswana (2009). This paper study results are of significant practical importance for policy makers in charge of designing efficient and growth promoting economic policies in Poland. Monetary policy targeted to drive economic growth up must take into the account that expansive monetary policy supports economic growth and in turn economic growth affect financial markets development. Paper results have also important implication for further research in the field. Time series data and empirical results for Poland show lending policy determines credit structure and in end economic growth dynamics. Mortgage lending (households' credits) versus investments lend-

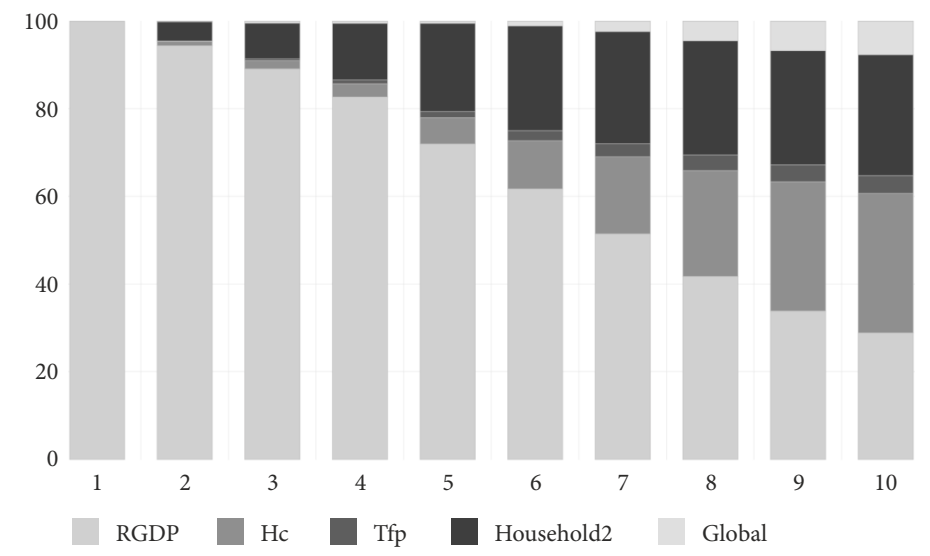

Figure 7. Variance decomposition of RGDP (with Households2) (source: authors' calculations)

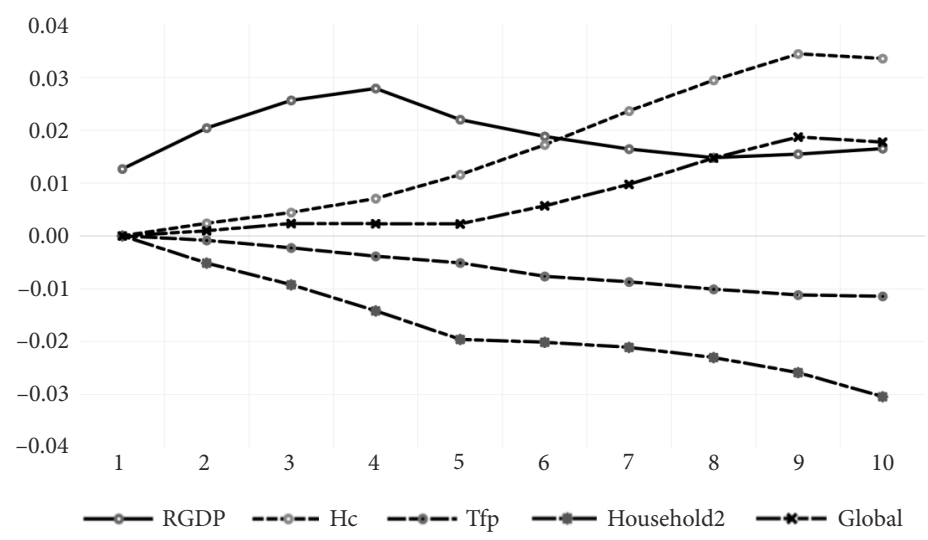

Figure 8. Response of RGDP to innovation (Shocks) (with Households2) (source: authors' calculations) 
ing (enterprise lending) differently affect economic growth in Poland. Academic studying the finance-growth nexus should in future research study disaggregate lending data (household and enterprise lending separately). They should also monitor the long memory nature of the financial time series data and explore the finance-growth link using long memory models (ARFIMA, VARFIMA, SVARFIMA).

The results of the study are limited to one country analysis over a sample of countries. Empirical results found for Poland cannot be by default implied for other former socialist countries, although it is excepted that the situation will look the same for most of the transitional economies (former and current). Although the VECM model explains a large part of the dynamics in the real GDP in Poland 1990-2012 with adjusted R-squared of 0.71, other factors such as automatization, foreign direct investments, IT sector development, convergence to the EU, outside the EURO zone could be important for the model. Although VECM applied in this study passes the standard model stability test, some series properties point to a possible presence of long memory and persistence. Under the long memory assumption and persistence in the series, more robust results could be obtained for the study of the impact of financial development on economic growth by using fractional integration model over a larger sample of countries.

The results suggest that disaggregation of total bank lending into household credit share (in \%) as well as firm credit share (in \%) in the total private credit by deposit money banks and other financial institutions is important for better understanding of the impact of financial development on economic growth. By using variable (Household2) for household share in total private credits by deposit money banks and other financial institutions it was observed that for 1\% increase in the household lending, the real GDP in Poland rose by $1.47 \%$. In the case of (Firms2) the share of firms in total private credits by deposit money banks and other financial institutions, it was noted that for $1 \%$ increase in the firm lending real GDP grew by $1.66 \%$. When using the standard variable (Credit) for measuring financial development level, such as private credit by deposit money banks and other financial institutions to GDP (in \%) it can be seen that the impact on economic growth is much lower, i.e., $0.37 \%$ per $1 \%$ increase in Credit. When using values of private credit share in the GDP, study results on the financial development and economic growth nexus tend to be undervalued. In this sense, the results do not reflect the real impact of financial development on output. In the case of Poland, the 'supply-leading' hypothesis stating that financial development leads to economic growth is proved. The 'demand-following hypothesis' is also verified and shows that economic growth in Poland affects financial sector development in the long run. The 'feedback-hypothesis' also holds, since there was observed evidence of bi-directional causality between financial development and economic growth in Poland. Moreover, it was proved that financial development and economic growth share a nexus in the short as well in the long run.

Future research should take into the account larger sample of countries, preferably a group of countries in transition and advanced economies. Studying countries in transition could lead to the discovery of particular monetary and fiscal policy mistakes that have an impact on the financial sector development. Furthermore, this can point out both the role of the National banks, as well as economic expectations of the population and management 
behavior in the banks. All of these findings could have an important effect on the financial development resulting in similar monetary policies guidelines but in reality, completely inverse impact on the real sector because of the asymmetries in the bank behavior and lending practice.

\section{Conclusions}

This study provides evidence for the importance of financial development (measured through lending activity) to the output growth in Poland during 1990-2018. The analysis distinguishes the importance of the lending structure (credits to household vs credits to firms) within the financial sector. It was found that a bidirectional Granger causality exists between financial development and economic growth in Poland, both in the short and long run. The findings are also in line with the 'supply-leading' and 'demand-following' hypothesis. Financial development in the case of Poland plays an active and important role in supporting economic growth. At the same time, development in the real sector through rise in real GDP, total factor productivity and human capital stock led to faster and further development in the financial sector itself. However, the extent and persistence of the financial development on economic growth depends on the lending structure - firms lending over household lending, investments in machinery and equipment over mortgage lending. It is the same lending structure that will, in the end, determine the extent of the financial development impact on economic growth. This means that it is not important how much money financial system lends, but to whom and for what purpose.

The results of the study suggest that by incorporating household and firm lending as proxy for financial development, the way in which the financial development facilitates economic growth could be understood better. Policy Central banks should pay close attention to the structure of bank lending and tightness of monetary policy since this could have negative effects on economic growth in the long run. These are lessons particularly important for the policy makers in the transitional and developing countries. Financial development facilitates economic growth, while in turn, growth leads to the development of the financial sector. Although 'neutral hypothesis' does not hold for Poland, it is expected valid for most of the ex-socialist economies. These findings are also important for bank owners and management. Distorted lending activities (asymmetrical lending that does not consider economic expectations, stock market movements and interest rates policy management) in the long run could expose them to galloping levels of non-performing loans issuing. This particular holds for the banking sector in the EURO zone.

Although financial development facilitates economic growth, it is the structure of the financial development (bank credit structure) that determines its final impact (extent and sign) on economic growth in the short run, and even more in the long run. Policy makers should promote economic policy relying on investments lending and not mortgage lending in order to boost economic growth, particularly in the long run. Financial lending show to have long lasting effects on economic growth and in turn economic growth promotes development of the financial markets in Poland. Researchers should study the persistence and long memory nature of the financial time series data and reflect on using long memory models (ARFIMA, VARFIMA, SVARFIMA) in studying the financial-growth nexus. 
Although study results are limited to Poland (case study research), we find the result robust to model change so similar results can be expected to hold also for other countries as well. Further research on the finance-growth nexus should explore the long memory nature of the financial data and use fractional integration modelling to explore the relationship properly.

\section{References}

Afonso, A., \& Blanco-Arana, C. (2018). Financial development and economic growth: A study for OECD countries in the context of crisis (REM Working Paper 046-2018). https://doi.org/10.2139/ssrn.3224317

Ahlin, Ch., \& Pang, J. (2008). Are financial development and corruption control substitutes in promoting growth?. Journal of Development Economics, 86(2), 414-433.

https://doi.org/10.1016/j.jdeveco.2007.07.002

Akaike, H. (1974). A new look at the statistical model identification. IEEE Transactions on Automatic Control, 19(6), 716-723. https://doi.org/10.1109/TAC.1974.1100705

Angjelkovska, T., Hani, E., \& Eliskovski, M. (2016). The effect of enterprise and household credit on economic growth and real exchange rate dynamics: Evidence from SEE countries (Working Paper). National Bank of the Republic of Macedonia, Skopje.

Asteriou, D., \& Spanos, K. (2018). The relationship between financial development and economic growth during the recent crisis: Evidence from the EU. Finance Research Letters (in Press). https://doi.org/10.1016/j.frl.2018.05.011

Bahadir, B., \& Valev, N. (2017). Catching up or drifting apart: Convergence of household and business credit in Europe. International Review of Economics \& Finance, 47, 101-114. https://doi.org/10.1016/j.iref.2016.10.006

Bangake, Ch., \& Eggoh, J. C. (2011). Further evidence on finance-growth causality: A panel data analysis. Economic Systems, 35(2), 176-188. https://doi.org/10.1016/j.ecosys.2010.07.001

Bank for International Settlements. (2018, June). BIS statistics. Retrieved from https://www.bis.org/ statistics/

Baumol, W. J., \& Bowen, W. G. (1966). Performing arts: The economic dilemma. New York: Twentieth Century Fund.

Beck, T., \& Levine, R. (2002). Industry growth and capital allocation: Does having a market- or bankbased system matter? Industry growth and capital allocation: Does having a market- or bank-based system matter?. Journal of Financial Economics, 64(2), 147-180. https://doi.org/10.1016/S0304-405X(02)00074-0

Beck, T., Buyukkarabacak, B., Rioja, F., \& Valev, N. (2008). Who gets the credit ? and does it matter? household vs. firm lending across countries (Policy Research Working Paper Series 4661). Washington, D.C.: World Bank.

Beck, T., Demirgüç-Kunt, A., \& Levine, R. (2000). A new database on financial development and structure. World Bank Economic Review, 14(3), 597-605. https://doi.org/10.1093/wber/14.3.597

Beck, T., Demirgüç-Kunt, A., \& Levine, R. (2009). Financial institutions and markets across countries and over time: Data and analysis (World Bank Policy Research Working Paper 4943). Washington, D.C.: World Bank.

Beck, T., Levine, R., \& Loayza, N. (2000). Finance and the sources of growth. Journal of Financial Economics, 58(1-2), 261-300. https://doi.org/10.1016/S0304-405X(00)00072-6

Belinga, T., Zhou, J., Doumbe-Doumbe, E., Gahe, Z. S. Y., \& Koffi, Y. S. L. (2016). Causality relationship between bank credit and economic growth: Evidence from a time series analysis on a vector error correction model in Cameroon. Procedia - Social and Behavioral Sciences, 2(35), 664-671. 
Benhabib, J., \& Spiegel, M. (2000). The role of financial development in growth and investment. Journal of Economic Growth, 5(4), 341-60. https://doi.org/10.1023/A:1026599402490

Berthelemy, J.-C., \& Varoudakis, A. (1996). Economic growth, convergence clubs, and the role of financial development. Oxford Economic Papers, 48(2), 300-328.

https://doi.org/10.1093/oxfordjournals.oep.a028570

Bordo, M. D., \& Rousseau, P. L. (2006). Legal-political factors and the historical evolution of the finance-growth. European Review of Economic History, 10(3), 421-444.

https://doi.org/10.1017/S136149160600181X

Calderón, C., \& Liu, L. (2003). The direction of causality between financial development and economic growth. Journal of Development Economics, 72(1), 321-334. https://doi.org/10.1016/S0304-3878(03)00079-8

Carby, Y., Craigwell, R., Wright, A., \& Wood, A. (2012). Finance and growth causality: A test of the Patrick's stage-of-development hypothesis. International Journal of Business and Social Science, 3(21), 129-139.

Christopoulos, D. K., \& Tsionas, E. (2004). Financial development and economic growth: evidence from panel unit root and cointegration tests. Journal of Development Economics, 73(1), 55-74. https://doi.org/10.1016/j.jdeveco.2003.03.002

Chudik, A., Mohaddes, K., Pesaran, M. H., \& Raissi, M. (2017). Is there a debt-threshold effect on output growth? Review of Economics and Statistics, 99(1), 135-150. https://doi.org/10.1162/REST_a_00593

Cihák, M., Demirguc-Kunt, A., Feyen, E., \& Levine, R. (2012). Benchmarking financial systems around the world (World Bank Policy Research Working Paper 6175). Washington, D.C: World Bank.

Credit Structure Database [CSD]. (2018, June). Retrieved from https://sites.google.com/site/florianleon/ research/data

De Gregorio, J. (1996). Borrowing constraints, human capital accumulation, and growth. Journal of Monetary Economics, 37(1), 49-71. https://doi.org/10.1016/0304-3932(95)01234-6

Deidda, L., \& Fattouh, B. (2002). Non-linearity between finance and growth. Economics Letters, 74(3), 339-345. https://doi.org/10.1016/S0165-1765(01)00571-7

Demetriades, P. O., \& Hussein, K. A. (1996). Does financial development cause economic growth? Time-series evidence from 16 countries. Journal of Development Economics, 51(2), 387-411. https://doi.org/10.1016/S0304-3878(96)00421-X

Demetriades, P., \& Law, S. H. (2006). Finance, institutions and economic development. International Journal of Finance and Economics, 11(3), 245-260. https://doi.org/10.1002/ijfe.296

Deuber, G. (Ed.). (2017, June). CEE banking sector report. Banking sector convergence 4.0. Raiffeisen research. Retrieved from https://www.rbinternational.com/eBusiness/services/resources/ media/829189266947841370-829188968716049154-1248005137162522516-1-2-EN-8.pdf

Dickey, D., \& Fuller, W. (1979). Distribution of the estimators for autoregressive time series with a unit root. Journal of the American Statistical Association, 74(366), 427-431. https://doi.org/10.2307/2286348

Ductor, L., \& Grechyna, D. (2015). Financial development, real sector, and economic growth. International Review of Economics \& Finance, 37, 393-405. https://doi.org/10.1016/j.iref.2015.01.001

Durusu-Ciftci, D., SerdarIspir, M., \& Yetkiner, H. (2017). Financial development and economic growth: Some theory and more evidence, Journal of Policy Modeling, 39(2), 290-306. https://doi.org/10.1016/j.jpolmod.2016.08.001

European Bank of Reconstruction and Development. (2017). EBRD Financial Report 2017 (923 Financial Report 2017 (E/1,000)). Retrieved from https://www.ebrd.com/news/publications/financialreport/ebrd-financial-report-2017.html 
Favara, G. (2003). An empirical reassessment of the relationship between finance and growth. Washington, DC: IMF.

Feenstra, R. C., Inklaar, R., \& Timmer, M. P. (2015). The next generation of the Penn World Table. American Economic Review, 105(10), 3150-3182. https://doi.org/10.1257/aer.20130954

Fink, G., Haiss, P. R., \& Mantler, H. C. (2005). The finance-growth nexus: Is there a difference between market economies and transition countries?. Retrieved from SSRN https://ssrn.com/abstract $=676843$ https://doi.org/10.2139/ssrn.676843

Folwarski, M. (2016). Wpływ kredytów bankowych na wzrost gospodarczy w Polsce. Journal of Financial Management and Accounting, 4(3), 5-14.

Galor, O., \& Zeira, J. (1993). Income distribution and macroeconomics. The Review of Economic Studies, 60(1), 35-52. https://doi.org/10.2307/2297811

Ganiyu, B. A., Amoo, M. I., Eboreime, Y. A., \& Maximillian, C. B. (2017). The impact of private sector credit on economic growth in Nigeria. CBN Journal of Applied Statistics, 8(2), 81-101.

Gygli, S., Haelg, F., \& Sturm, J.-E. (2018). The KOF globalisation index - revisited (KOF Working Papers, No. 439). KOF Swiss Economic Institute.

Goldsmith, R. W. (1969). Financial structure and development. New Haven, CT: Yale University Press.

Gómez-Puig, M., \& Sosvilla-Rivero, S. (2018). Non financial debt and economic growth in euro-area countries. Journal of International Financial Markets Institutions and Money, 56, 17-37. https://doi.org/10.1016/j.intfin.2018.03.005

Granger, C. (1969). Investigating causal relations by econometric models and cross-spectral methods. Econometrica, 37(3), 424-438. https://doi.org/10.2307/1912791

Hasan, I., Horvath, R., \& Mares, J. (2016). What type of finance matters for growth? Bayesian model averaging evidence (English) (Policy Research working paper, No. WPS 7645). Washington, D.C.: World Bank Group. Retrieved from http://documents.worldbank.org/curated/en/859201468186859436/ What-type-of-finance-matters-for-growth-Bayesian-model-averaging-evidence

Ibrahim,' M., \& Alagidede, P. (2018). Effect of financial development on economic growth in sub-Saharan Africa. Journal of Policy Modeling, 40(6), 1104-1125. https://doi.org/10.1016/j.jpolmod.2018.08.001

Ivanović, V., \& Stanišić, N. (2017). Monetary freedom and economic growth in New European Union Member States. Economic Research-Ekonomska Istraživanja, 30(1), 453-463. https://doi.org/10.1080/1331677X.2017.1305803

Jappelli, T., \& Pagano, M. (1994). Saving, growth, and liquidity constraints. The Quarterly Journal of Economics, 109(1), 83-109. https://doi.org/10.2307/2118429

Jedidia, K. B., Boujelbènec, B., \& Helali, K. (2014). Financial development and economic growth: New evidence from Tunisia. Journal of Policy Modeling, 36(5), 883-898. https://doi.org/10.1016/j.jpolmod.2014.08.002

Johansen, S. (1991). Estimation and hypothesis testing of cointegration vectors in Gaussian vector autoregressive models. Econometrica, 59(6), 1551-1580. https://doi.org/10.2307/2938278

Johansen, S., \& Juselius, K. (1990). Maximum likelihood estimation and inference on cointegration with applications to the demand for money. Oxford Bulletin of Economics and Statistics, 52(2), 169-210. https://doi.org/10.1111/j.1468-0084.1990.mp52002003.x

Johansen, S. (1995). Likelihood-based inference in cointegrated vector autoregressive models. New York: Oxford University Press. https://doi.org/10.1093/0198774508.001.0001

Katircioglu, S. T., Kahyalar, N., \& Benar, H. (2007). Financial development, trade and growth triangle: The case of India. International Journal of Social Economics, 34(9), 586-598. https://doi.org/10.1108/03068290710778615

King, R. G., \& Levine, R. (1993). Finance and growth: Schumpeter might be right. The Quarterly Journal of Economics, 108(3), 717-737. https://doi.org/10.2307/2118406 
Koivu, T. (2002). Do efficient banking sectors accelerate economic growth in transition countries?. Macroeconomics, 0212013. University Library of Munich, Germany.

Komisja Nadzoru Finansowego [KNF]. (2018, June). KNF - Polish Financial Supervision Authority. Statistic data. Retrieved from https://www.knf.gov.pl/en/

Kwiatkowski, D., Phillips, P. C. B., Schmidt, P., \& Shin, Y. (1992). Testing the null hypothesis of stationarity against the alternative of a unit root How sure are we that economic time series have a unit root? Journal of Econometrics, 54(1-3), 159-178. https://doi.org/10.1016/0304-4076(92)90104-Y

Léon, F. (2016). Enterprise credit, household credit and growth: New evidence from 126 countries (CREA Discussion Paper 2016-2017). 1-42. University of Luxembourg.

Léon, F. (2018a). The credit structure database (CREA Discussion Paper Series 2018-07). University of Luxembourg.

Léon, F. (2018b). Convergence of credit structure around the world. Economic Modelling, 68(C), 306317. https://doi.org/10.1016/j.econmod.2017.07.021

Levine, R. (1997). Financial development and economic growth: Views and agenda. Journal of Economic Literature, 35(2), 688-726.

Levine, R. (2005). Finance and growth: Theory and evidence. In Ph. Aghion, \& S. Durlauf (Eds.), Handbook of economic growth (Vol. 1, Chapter 12, pp. 865-934). Elsevier. https://doi.org/10.1016/S1574-0684(05)01012-9

Levine, R., Loayza, N., \& Beck, T. (2000). Financial intermediation and growth: Causality and causes. Journal of Monetary Economics, 46(1), 31-77. https://doi.org/10.1016/S0304-3932(00)00017-9

Ljung, G. M., \& Box, G. E. P. (1978). On a measure of lack of fit in time series models. Biometrika, 65(2), 297-303. https://doi.org/10.1093/biomet/65.2.297

Loayza, N., \& Ranciere, R. (2005). Financial development, financial fragility and growth (IMF Working Paper, WP/05/170, 1-31/). International Monetary Fund.

Luintel, K. B., \& Khan, M. (1999). A quantitative reassessment of the finance-growth nexus: evidence from a multivariate VAR. Journal of Development Economics, 60(2), 381-405. https://doi.org/10.1016/S0304-3878(99)00045-0

Lütkepohl, H. (2005). New introduction to multiple time series analysis (764 p.). Berlin: Springer-Verlag. https://doi.org/10.1007/978-3-540-27752-1

Maswana, J. C. (2009). A contribution to the empirics of finance-growth Nexus in China: A complex system perspective. Global Economic Review, 38(1), 29-47. https://doi.org/10.1080/12265080802692662

McKinnon, R. I. (1973). Money and capital in economic development. Washington, DC: Brookings Institution.

Neusser, N., \& Kugler, M. (1998) Manufacturing growth and financial development: Evidence from OECD countries. Review of Economics and Statistics, 80(4), 636-646. https://doi.org/10.1162/003465398557726

Odedokun, M. (1996). Financial policy and efficiency of resource utilization in developing countries. Growth and Change, 27(3), 269-297. https://doi.org/10.1111/j.1468-2257.1996.tb00906.x

Odhiambo, N. M. (2005). Financial development and economic growth in Tanzania: a dynamic causality tests. African Finance Journal, 7(1), 1-17.

Ono, S. (2017). Financial development and economic growth nexus in Russia. Russian Journal of Economics, 3(3), 321-332. https://doi.org/10.1016/j.ruje.2017.09.006

Penn World Table 9.1. (2018, June). The Database. https://doi.org/10.15141/S5J01T

Phillips, P. C. B., \& Perron, P. (1988). Testing for a unit root in time series regression. Biometrika, 75(2), 335-346. https://doi.org/10.1093/biomet/75.2.335 
Ram, R. (1999). Financial development and economic growth: Additional evidence. Journal of Development Studies, 35(4), 164-174. https://doi.org/10.1080/00220389908422585

Rioja, F., \& Valev, N. (2004a). Does one size fit all? A reexamination of the finance and growth relationship. Journal of Development Economics, 74(2), 429-447.

https://doi.org/10.1016/j.jdeveco.2003.06.006

Rioja, F., \& Valev, N. (2004b). Finance and the sources of growth at various stages of economic development. Economic Inquiry, 42(1), 127-140. https://doi.org/10.1093/ei/cbh049

Rousseau, P. L., \& Wachtel, P. (2002). Inflation thresholds and the finance-growth nexus. Journal of International Money and Finance, 21(6), 777-793. https://doi.org/10.1016/S0261-5606(02)00022-0

Ruiz, J. L. (2018). Financial development, institutional investors, and economic growth. International Review of Economics \& Finance, 54, 218-224. https://doi.org/10.1016/j.iref.2017.08.009

Samargandia, N., Fidrmuc, J., \& Ghosh, S. (2015). Is the relationship between financial development and economic growth monotonic? Evidence from a sample of middle-income countries. World Development, 68, 66-81. https://doi.org/10.1016/j.worlddev.2014.11.010

Sassi, S., \& Gasmi, A. (2014). The effect of enterprise and household credit on economic growth: New evidence from European union countries. Journal of Macroeconomics, 39(A), 226-231.

Schwarz, G. (1978). Estimating the dimension of a model. The Annals of Statistics, 6(2), 461-464. https://doi.org/10.1214/aos/1176344136

Shan, J., \& Jianhong, Q. (2006). Does financial development lead's economic growth? The case of China. Annals of Economics and Finance, 7(1), 197-216.

Topcu, M., \& Çoban, S. (2017). Financial development and firm growth in Turkish manufacturing industry: evidence from heterogeneous panel based non-causality test. Economic Research-Ekonomska Istraživanja, 30(1), 1758-1769. https://doi.org/10.1080/1331677X.2017.1383179

Wiiw Annual Database. (2018, June). Retrieved from https://data.wiiw.ac.at/annual-database.html

World Bank. (2018a, June). Financial development and structure dataset. Retrieved from http://www. worldbank.org/en/publication/gfdr/data/financial-structure-database

World Bank. (2018b, June). Global financial development database (GFDD). Retrieved from https:// www.worldbank.org/en/publication/gfdr/data/global-financial-development-database

World Bank. (2018c, June). World development indicators. Retrieved from http://datatopics.worldbank. org/world-development-indicators/

Yülek, M. A. (2017). Why governments may opt for financial repression policies: selective credits and endogenous growth. Economic Research-Ekonomska Istraživanja, 30(1), 1390-1405. https://doi.org/10.1080/1331677X.2017.1355252

Zang, H., \& Kim, Y. C. (2007). Does financial development precede growth? Robinson and Lucas might be right. Applied Economics Letters, 14(1), 15-19. https://doi.org/10.1080/13504850500425469 